\title{
On the Rising Complexity of Bank Regulatory Capital Requirements: From Global Guidelines to their United States (US) Implementation
}

\author{
James R. Barth ${ }^{1}$ and Stephen Matteo Miller ${ }^{2, *}$ \\ 1 Lowder Eminent Scholar in Finance, Auburn University, Auburn, AL 36849, USA; barthjr@auburn.edu \\ 2 Senior Research Fellow, Mercatus Center at George Mason University, Fairfax, VA 22030, USA \\ * Correspondence: smiller@mercatus.gmu.edu
}

Received: 2 October 2018; Accepted: 30 October 2018; Published: 1 November 2018

\begin{abstract}
After the Latin American Debt Crisis of 1982, the official response worldwide turned to minimum capital standards to promote stable banking systems. Despite their existence, however, such standards have still not prevented periodic disruptions in the banking sectors of various countries. After the 2007-2009 crisis, bank capital requirements have, in some cases, increased and overall have become even more complex. This paper reviews (1) how Basel-style capital adequacy guidelines have evolved, becoming higher in some cases and overall more complex, (2) how the United States (US) implementation of these guidelines has contributed to regulatory complexity, even when omitting other bank capital regulations that are specific to the US, and (3) how the US regulatory measures still do not provide equally valuable information about whether a bank is adequately capitalized.
\end{abstract}

Keywords: bank regulation; capital adequacy standards; regulatory complexity; US banking crises

JEL Classification: G01; G28; K20; L51; N22; N42

\section{Introduction ${ }^{1}$}

Banks are vital in facilitating the exchange of goods and services by providing a payment system and channeling savings to productive investment projects that foster economic activity. However, banking crises have historically contributed to declines in overall economic activity. Furthermore, the ensuing policy response to crises often calls for implementing a variety of banking reforms that may be ineffective or even undermine existing policies (e.g., White (2013); Herring $(2016,2018)$ ).

Capital requirements can be an important tool that bank regulators use to promote a well-functioning banking system, presuming that sufficient levels of owner-contributed equity capital improve a bank's ability to withstand large shocks to asset values. These requirements have grown increasingly complexity in recent decades (see Haldane (2011); and, Herring $(2016,2018)$ ). Fully understanding their nuances presents a challenge, even for those who have spent substantial time studying them. Further adding to the challenge is the existence of multiple capital requirements that are satisfied by different items.

This review of bank capital regulation discusses the growing complexity of Basel capital adequacy guidelines, which, when implemented by a country's regulators, pose a challenge for bank regulatory compliance, oversight, and academic and policy analysis. As evidence of that growing complexity we

1 The authors are extremely grateful for helpful comments provided by three referees, and would also like to thank Hester Peirce, Tracy Miller, Jerry Ellig and Thomas Stratmann for valuable feedback. Also, Yanfei Sun provided excellent assistance in helping the authors collect information and prepare all the tables for the paper. 
show that regulatory capital requirements can generate up to 25 percent of all regulatory restrictions and on average thousands of additional words embodied in the parts of the United States (US) Code of Federal Regulations (CFR) that concern banks.

We also show that despite the increased complexity of the regulatory capital ratios, they do not provide equally valuable information about whether a bank is adequately capitalized. The data presented clearly indicate that whether banks have too little capital or excess capital depends on the specific capital ratio on which one focuses and whether the capital ratio is based on the riskiness of a bank's business model. Some ratios may indicate that a bank has sufficient capital while other ratios indicate the opposite. A higher regulatory capital ratio that is imposed on banks may or may not affect bank behavior. The specific ratio that regulators choose to increase is crucial. In the aggregate, the market knows that not all ratios are equally revealing about a bank's actual capital adequacy, and thus some ratios receive more attention than others. Given this situation, emphasis could be placed on a straightforward and easily understood capital ratio that market participants have always paid attention to when they assess whether a bank is adequately capitalized. Indeed, some recent studies show that the benefits outweigh the costs (e.g., Karmakar (2016); Begenau and Landvoigt (2017); Egan et al. (2017); Barth and Miller (2018)).

The remainder of the paper proceeds, as follows. The next section summarizes the Basel Capital Accords and their US implementation. Section 3 discusses additional regulatory measures that US regulators apply, including Prompt and Corrective Action (PCA), comprehensive capital analyses, and supervisory stress testing to which regulators now subject the larger banks. PCA describes the actions that banking regulators are legally required to take as a bank's capital declines below specified minimum levels. This is important because, based on publicly available information, researchers are able to determine whether the regulatory authorities actually take the actions that are required when banks encounter financial difficulties. Section 4 explains that the new capital requirements have generated considerable controversy because they require banks to hire more employees with quantitative skills, which results in an increase in costs without a corresponding increase in revenues. It is not clear, moreover, whether the more extensive analyses and testing contribute to a safer and sounder banking system. Section 5 concludes with a suggestion for greater emphasis on a minimum required capital ratio that eliminates most of the confusion over determining whether a bank is adequately capitalized-one that market participants themselves relied on during the most recent banking crisis of 2007-2009.

\section{Capital Adequacy Standards: Basel Guidelines and Their US Implementation}

\subsection{Basel Capital Adequacy Guidelines}

The central bank governors of the G10 countries established a Committee on Banking Regulations and Supervisory Practices at the end of 1974 following disruptions in the international financial markets after the breakdown of the Bretton Woods system of managed exchange rates (Kapstein 1991, 1994). The committee was later renamed the Basel Committee on Banking Supervision (BCBS). The aim of that committee was and is to promote financial stability by improving banking supervision worldwide. The BCBS seeks to accomplish its aims by establishing minimum standard guidelines for the regulation and supervision of large, internationally active banks. Since its first meeting in February 1975 (see Kapstein 1991, 1994), the BCBS has been meeting regularly three or four times a year. Membership was expanded beyond the G10 in 2009 and again in 2014, so that 28 jurisdictions - 27 countries and the European Union—are now included in the BCBS. ${ }^{2}$ BCBS decisions are recommendations, and are

2 See "Basel Committee Membership" page, Bank for International Settlements, last updated 30 December 2016, http: //www.bis.org/bcbs/membership.htm. 
thus not legally binding on the member jurisdictions, but the BCBS "expects full implementation of its standards by its member jurisdictions and their internationally active banks". ${ }^{3}$

The Latin American debt crisis of the early 1980s generated concerns about the adequacy of the capital of the large international banks (Kapstein 1991, 1994). In response, Congress passed the International Lending Supervision Act of 1983, in part to get US regulators to find a way to raise capital requirements in a multilateral way since differences existed in national capital requirements and concerns existed that these differences would adversely affect banks in the US (Kapstein 1991, 1994). ${ }^{4}$ Through the BCBS, these efforts culminated in the first Basel Capital Accord (Basel I) in July 1988. Basel I called for a minimum capital ratio, which was based on capital relative to risk-weighted assets (RWAs).

Table 1 offers a summary of the various capital requirements across Basel regimes, which under Basel I, included two tiers of capital, Tier 1 and Tier 2, which combined to form total capital, and these capital measures based on accounting or book values. We list the composition of the different capital concepts are listed in Table 2. Tier 1 capital was initially set at 3.625 percent of RWAs and then increased to 4 percent by the end of 1992, while total capital was increased from 7.25 percent to 8 percent of RWAs over the same period. The BCBS did not recommend a leverage ratio, or non-risk-based capital ratio, at the time.

However, the BCBS intended these capital ratios to evolve over time as events unfolded and new information became available. In January 1996, for example, the BCBS issued guidelines within Basel I to incorporate market risks in capital requirements, since initially only credit risks were addressed (Basel Committee on Banking Supervision BCBS). This new capital requirement took into account the risk of losses in on-balance-sheet and off-balance-sheet positions arising from movements in market prices. At the same time, a third kind of regulatory capital, Tier 3, became part of total capital (Basel Committee on Banking Supervision BCBS). These changes were to take effect at the end of 1997 and allowed banks, for the first time, to use internal models (value-at-risk models) as a basis for calculating their market-risk capital requirements.

In June 2004, the BCBS replaced the Basel Capital Accord (Basel I) with the Revised Capital Framework (Basel II) (Basel Committee on Banking Supervision BCBS). Basel II was made up of three pillars: Pillar I, which was designed to develop and expand the minimum capital requirements in Basel I; Pillar II, which provided for supervisory review of a bank's capital adequacy and internal assessment process; and, Pillar III, which called for the effective use of disclosure as a lever to strengthen market discipline and encourage sound banking practices. The minimum required risk-based capital ratios for Tier 1 and total capital were left unchanged at 4 percent and 8 percent, respectively, as shown in Table 1. The BCBS member countries and several non-member countries agreed to adopt the new guidelines, but on varying national timescales. ${ }^{5}$

The BCBS agreed to Basel II.5 in July 2009 as a revision of Basel II, which BCBS members believed had failed to properly address market risk that banks took on their trading books. Basel II.5 introduced an incremental risk charge (IRC) to estimate and capture default and credit migration risk (i.e., the risk when customers move their loans from one bank to another bank). Basel II.5 also introduced an additional charge to compensate for an increase in one risk that leads to an increase in another risk (i.e., correlated risk). In addition, BCBS introduced stressed value-at-risk to require banks to calculate capital requirements under stress conditions. Lastly, standardized charges were introduced for securitization and re-securitization positions.

3 See "Policy Development and Implementation Review", Bank for International Settlements, as of the 30 December 2016 update, https://www.bis.org/bcbs/review_process.htm.

4 For the International Lending and Supervision Act of 1983, see Title IX of Public Law No. 98-181, 97 Stat. 1278.

5 By 2014, all 27 BCBS member countries had implemented or were in the process on implementing Basel II (meaning at least one subsection had been implemented), while another 94 non-BCBS jurisdictions had done the same (see Basel Committee on Banking Supervision BCBS). 
Table 1. A Timeline of Basel Capital Accords.

\begin{tabular}{|c|c|c|c|c|c|c|c|c|c|c|}
\hline \multirow{2}{*}{ Regulatory Capital Standards } & \multirow{2}{*}{$\begin{array}{c}\text { Basel I }^{a}(\%) \\
1993-2010 \\
\end{array}$} & \multirow{2}{*}{$\begin{array}{c}\text { Basel II }^{b}(\%) \\
2011 \\
\end{array}$} & \multirow{2}{*}{$\begin{array}{c}\text { Basel II. } 5^{c}(\%) \\
2012 \\
\end{array}$} & \multicolumn{7}{|c|}{ Basel III $^{d}(\%)$} \\
\hline & & & & 2013 & 2014 & 2015 & 2016 & 2017 & 2018 & as of 1 January 2019 \\
\hline $\begin{array}{l}\text { Minimum Tier } 1 \text { capital (CET1 plus } \\
\text { additional Tier 1) }\end{array}$ & 4.0 & 4.0 & 4.0 & 4.5 & 5.5 & 6.0 & 6.0 & 6.0 & 6.0 & 6.0 \\
\hline $\begin{array}{l}\text { Minimum total capital (Tier } 1 \text { plus Tier } 2 \\
\text { capital) }\end{array}$ & 8.0 & 8.0 & 8.0 & 8.0 & 8.0 & 8.0 & 8.0 & 8.0 & 8.0 & 8.0 \\
\hline $\begin{array}{l}\text { Common equity leverage ratio }{ }^{e} \text { (viewed } \\
\text { as a backstop to risk-based ratios) }\end{array}$ & $\mathrm{n} / \mathrm{a}$ & $\begin{array}{l}\text { supervisory } \\
\text { monitoring }\end{array}$ & \multicolumn{6}{|c|}{ test period and disclosure starts 1 January 2015} & 3.0 & 3.0 \\
\hline Minimum CET1 capital ratio & $\mathrm{n} / \mathrm{a}$ & 2.0 & 2.0 & 3.5 & 4.0 & 4.5 & 4.5 & 4.5 & 4.5 & 4.5 \\
\hline Capital conservation buffer & $\mathrm{n} / \mathrm{a}$ & $\mathrm{n} / \mathrm{a}$ & $\mathrm{n} / \mathrm{a}$ & $\mathrm{n} / \mathrm{a}$ & $\mathrm{n} / \mathrm{a}$ & $\mathrm{n} / \mathrm{a}$ & 0.625 & 1.25 & 1.875 & 2.50 \\
\hline $\begin{array}{l}\text { Countercyclical capital buffer } \\
\text { (discretionary, } 0.0 \% \text { to } 2.5 \% \text { ), to be filled } \\
\text { with Tier } 1 \text { capital }\end{array}$ & $\mathrm{n} / \mathrm{a}$ & $\mathrm{n} / \mathrm{a}$ & $\mathrm{n} / \mathrm{a}$ & $\mathrm{n} / \mathrm{a}$ & $\mathrm{n} / \mathrm{a}$ & $\mathrm{n} / \mathrm{a}$ & 0.625 & 1.25 & 1.875 & 2.50 \\
\hline $\begin{array}{l}\text { Capital surcharge for global systemically } \\
\text { important banks }\end{array}$ & $\mathrm{n} / \mathrm{a}$ & $\mathrm{n} / \mathrm{a}$ & $\mathrm{n} / \mathrm{a}$ & $\mathrm{n} / \mathrm{a}$ & $\mathrm{n} / \mathrm{a}$ & $\mathrm{n} / \mathrm{a}$ & 0.25 to 3.5 & 0.5 to 3.5 & 0.75 to 3.5 & 1 to 3.5 \\
\hline
\end{tabular}

Note: CET1 = common equity Tier 1, n/a = not applicable. ${ }^{a}$ Basel I was finalized in July 1988 and implemented over the period 1988-1992. The figures in the column for Basel I show the final capital standards after implementation. ${ }^{b}$ Basel II was finalized in June 2004 and implemented over the period 2007-2010. The figures in the column for Basel II show the final capital standards after implementation. ${ }^{c}$ Basel II.5 was finalized in July 2009 and meant to be implemented no later than 31 December 2011 . Basel II.5 enhanced the measurements of risks related to securitization and trading book exposures. ${ }^{d}$ Basel III was finalized in December 2010 and meant to be implemented over the period 2013-2018. ${ }^{e}$ The leverage ratio is calculated as the ratio of Tier 1 capital to balance-sheet exposures plus certain off-balance-sheet exposures. ${ }^{f}$ The phasing works by capping the amount that can be included in capital from 90 percent on 1 January 2013, and reducing this cap by 10 percent in each subsequent year. Sources: Documents by the Basel Committee on Banking Supervision at the Bank for International Settlements in January 2013, and reducing this cap by 10 percent in each subsequent year. Sources: Documents by the Basel Committee on Banking Supervision at the Bank for International Settlements in Basel, Switzerland: "International Convergence of Capital Measurement and Capital Standards", July 1988 (Basel Committee on Banking Supervision BCBS); "Amendment to the Capital
Accord to Incorporate Market Risks", January 1996. "Amendment to the Capital Accord to Incorporate Market Risks", June 2004; "Revisions to the Basel II Market Risk Framework-Final Accord to Incorporate Market Risks", January 1996; “Amendment to the Capital Accord to Incorporate Market Risks", June 2004; “Revisions to the Basel II Market Risk Framework-Final
Version”, July 2009 (Basel Committee on Banking Supervision BCBS); "Basel III: A Global Regulatory Framework for More Resilient Banks and Banking Systems-Revised Version June 2011", June 2011; "The G-SIB Assessment Methodology—Score Calculation”, November 2014a (Basel Committee on Banking Supervision BCBS); “Implementation of Basel Standards: A Report to G20 Leaders on Implementation of the Basel III Regulatory Reforms", November 2014b (Basel Committee on Banking Supervision BCBS); also Barth et al. 2012. 
Table 2. Components of Total Capital.

\begin{tabular}{ll}
\hline Tier 1 capital & $\begin{array}{l}\text { At least } 50 \text { percent of a bank's capital base to consist of a core element comprised of equity } \\
\text { capital and published reserves from post-tax retained earnings minus goodwill }\end{array}$ \\
\hline $\begin{array}{l}\text { Undisclosed reserves, asset revaluation reserves, general provisions / general loan-loss } \\
\text { reserves, hybrid (debt/equity) capital instruments and subordinated debt, and limited to a } \\
\text { maximum of } 100 \text { percent of the total of Tier } 1 \text { elements }\end{array}$ \\
\hline $\begin{array}{l}\text { Note: Tier } 1 \text { capital did not include goodwill, which is the present value of conjectural future profits arising from } \\
\text { an acquisition when the amount paid is in excess of the target firm's value, because its ability to absorb losses is }\end{array}$ \\
unclear. Goodwill shows up on the balance sheet, but is recognized as not being easily converted into cash. Sources: \\
Documents by the Basel Committee on Banking Supervision at the Bank for International Settlements in Basel, \\
Switzerland: "International Convergence of Capital Measurement and Capital Standards", July 1988; "Amendment \\
to the Capital Accord to Incorporate Market Risks", January 1996.
\end{tabular}

The BCBS issued Basel III in December 2010 and revised it in June 2011, after the global banking crisis. ${ }^{6}$ BCBS made the revisions to enhance the Basel framework and strengthen the three pillars that were established by Basel II (Basel Committee on Banking Supervision BCBS). The new framework (Basel III) also introduced several regulatory capital innovations. Basel III established new minimum common equity and Tier 1 requirements and added an additional layer of common equity (the capital conservation buffer), a countercyclical buffer, a leverage ratio (based on both a bank's on-balance-sheet assets and off-balance-sheet exposures regardless of risk weighting), and supplementary capital requirements for systemically important banks. Also introduced were a liquidity coverage ratio (intended to provide enough cash to cover funding needs over a 30-day period of stress) to be phased in from 1 January 2015, to 1 January 2019, and a longer-term net stable funding ratio (intended to address maturity mismatches over the entire balance sheet) to take effect as a minimum standard by 1 January 2018.

The final capital standards introduced by Basel III were to be phased in over time, as shown in Table 1. The recommended leverage standard will be 3 percent in 2019. The recommended Tier 1 risk-based capital standard will be 6 percent and the total risk-based capital standard will be 8 percent. If one adds the capital conservation and countercyclical capital buffers to the total capital standard, the capital ratio can be as high as 13 percent for some banks, and even as high as 16.5 percent if one adds a capital surcharge of 3.5 percent for global systemically important banks (GSIBs). ${ }^{7}$

The Financial Stability Board (FSB), which makes policy recommendations to G20 members, has proposed further increasing requirements on GSIBs through a total loss-absorbing capacity (TLAC) requirement. On top of the required minimum common equity Tier 1 (CET1) ratio of 4.5 percent, GSIBs would have to fund with an additional 11.5 percent of "loss absorbency" in the form of Tier 1 and Tier 2 capital relative to risk-weighted assets. This requirement would rise to 13.5 percent by 2022 . The FSB expects GSIBs to meet this requirement in part through long-term, unsecured debt, which can be converted into equity when a bank fails. The emphasis on convertible debt is meant to put an end to "too big to fail" by forcing bondholders rather than taxpayers to inject capital into a large bank that fails. ${ }^{8}$

6 On 7 December 2017, the BCBS released "Basel III: Finalising post-crisis reforms", available from https:/ /www.bis.org/ bcbs/publ/d424.htm (Basel Committee on Banking Supervision BCBS), which the industry has already begun referring to as "Basel IV". While the 2011 Basel III guidelines focused on perceived problems with the numerator in regulatory capital ratios, the 2017 "Basel IV" guildelines focus on perceived problems with the denominator in regulatory capital ratios by proposing new risk-weights. However, US regulators have not finalized regulations based on these guidelines so we omit them from the discussion here.

7 Under the supervisory review process, the second pillar of the Basel Capital Accord, supervisors may determine capital adequacy should be even higher based upon a bank's operating environment.

8 For a discussion of TLAC, including its implications for US banks, see Killian (2016). 


\subsection{US Bank Capital Requirements}

While the US has for the most part adopted Basel guidelines, important differences exist, and Table 3 shows how the US implementation has varied according to Basel I, Basel II, Basel II.5, and Basel III. ${ }^{9}$ One important difference between the Basel guidelines and the US implementation has been that, unlike the former, the latter has included a leverage capital requirement in addition to the risk-based capital requirements. In addition, the US implementation applies to every bank, although some differences exist based on the bank's asset size. The risk-based capital requirements provide an incentive for banks to focus more on assets with lower risk weights, which can lead banks to change their business models (e.g., see Merton (1995); Jones (2000); Brealey (2006); and, Miller (2018)).

Like Table 1, Table 3 reveals the growing complexity of regulatory capital requirements since Basel I, especially after US banking regulators issued the final rule regarding the Basel III implementation in July 2013. ${ }^{10}$ Basel III regulation intends to strengthen the definition of regulatory capital, increase the minimum risk-based capital requirements for all banks, and modify the requirements for how banks calculate risk-weighted assets. It also retains the generally applicable leverage ratio requirement that banking regulators believe to be a simple and transparent measure of capital adequacy that is credible to market participants and ensures that a meaningful amount of capital is available to absorb losses. It includes both "advanced approaches" for determining the risk weight of assets for the largest internationally active banking organizations and a standardized approach that will apply to all banking organizations, except small bank holding companies (BHCs) with less than $\$ 500$ million in assets. Basel III regulation became effective for advanced-approaches banks on 1 January 2014, and on 1 January 2015 for non-advanced-approaches banks. Also, advanced-approaches banks have to calculate standardized-approach RWAs in addition to advanced-approaches RWAs for purposes of applying the "Collins Floor", which establishes a bank's minimum capital ratios as the lower of its standardized-approach and advanced-approaches ratios. ${ }^{11}$

Under Basel III, there are several new and more stringent capital requirements, as well as different capital requirements for banks of different sizes and systemic importance. In particular, there is a new CET1 capital ratio set at 4.5 percent of risk-based assets. The Tier 1 capital ratio is set at 6 percent (an increase from 4 percent), while the total capital ratio remains at 8 percent. The capital requirements are more stringent for the advanced-approaches banks and a subset of those banks identified as GSIBs. Indeed, for GSIBs the sum of the minimum total capital, the capital conservation buffer, the countercyclical capital buffer, and the GSIB surcharge can be as high as 17.5 percent of risk-based assets. The Federal Reserve Board (FRB) in July 2015 established the methods that US GSIBs will use to calculate a risk-based capital surcharge, which is calibrated to each firm's overall systemic risk. ${ }^{12}$ In particular, the GSIBs are required to calculate their surcharges under two methods and use the higher of the two. The first method is based on the framework that was agreed to by BCBS and considers a GSIB's size, interconnectedness, cross-jurisdictional activity, substitutability, and complexity. The second method uses similar inputs, but it is calibrated to result in significantly higher surcharges and replaces substitutability with a measure of the bank's reliance on short-term wholesale funding. The surcharges are being phased in-implementation began on 1 January 2016, and it will become fully effective on 1 January 2019.

9 The table also reflects the effect of the implementation of the Dodd-Frank Act on capital requirements.

10 See Comptroller of the Currency, Federal Register 2013. To see how the new regulations increase complexity, Herring (2018) estimates that capital requirement have five distinct numerators and denominators, which generate 39 distinct capital requirements for US GSIBs; that estimate assumes all capital ratios were implemented in full, and the number would increase if the phase-in periods were used instead.

11 See Section 171 of the "Dodd-Frank Wall Street Reform and Consumer Protection Act," Public Law No. 111-203, 124 Stat. 1376.

12 The FSB and BCBS provide the list of GSIBs, using the assessment methodology published by BCBS. See Financial Stability Board, "2015 update of list of global systemically important banks (GSIBs)", 3 November 2015. See also Board of Governors of the Federal Reserve System, Federal Register 2015. 
Table 3. A Timeline of United States (US) Capital Requirements.

\begin{tabular}{|c|c|c|c|c|c|c|c|c|c|c|c|}
\hline \multirow[t]{2}{*}{ Regulatory Capital Requirements } & \multicolumn{2}{|c|}{$\begin{array}{l}\text { US minimum Capital } \\
\text { Standards Based on } \\
\text { Basel I }{ }^{a}(\%)\end{array}$} & \multirow{2}{*}{$\begin{array}{c}\begin{array}{c}\text { Basel II } \\
(\%)\end{array} \\
2011 \\
\end{array}$} & \multirow{2}{*}{$\begin{array}{c}\begin{array}{c}\text { Basel III.5 } \\
{ }^{c}(\%)\end{array} \\
2012 \\
\end{array}$} & \multicolumn{7}{|c|}{ Basel III ${ }^{d}(\%)$} \\
\hline & 1991-1992 & 1993-2010 & & & 2013 & 2014 & 2015 & 2016 & 2017 & 2018 & as of 1 January 2019 \\
\hline Minimum Tier 1 capital (CET1 + additional Tier 1) & 3.625 & 4.0 & 4.0 & 4.0 & 4.5 & 5.5 & 6.0 & 6.0 & 6.0 & 6.0 & 6.0 \\
\hline Minimum total capital (Tier $1+$ Tier 2 capital) & 7.25 & 8.0 & 8.0 & 8.0 & 8.0 & 8.0 & 8.0 & 8.0 & 8.0 & 8.0 & 8.0 \\
\hline $\begin{array}{l}\text { Tier } 1 \text { leverage ratio and supplementary leverage ratio } \\
\text { (viewed as a complement to risk-based ratios) })^{f}\end{array}$ & \multicolumn{6}{|c|}{4 (3 for banks that are CAMELS 1-rated) } & 4 & 4 & 4 & $\begin{array}{c}3 \text { (AA) } \\
5 \text { (GSIBs and } 6 \text { for } \\
\text { their IDIs) } \\
4 \text { (NAA) }\end{array}$ & $\begin{array}{c}3 \text { (AA) } \\
5 \text { (GSIBs and } 6 \text { for } \\
\text { their IDIs) } \\
4 \text { (NAA) }\end{array}$ \\
\hline $\begin{array}{l}\text { Minimum CET1 capital ratio (introduced in } 2009 \text { in the } \\
\text { United States) }\end{array}$ & $\mathrm{n} / \mathrm{a}$ & $\mathrm{n} / \mathrm{a}$ & $\mathrm{n} / \mathrm{a}$ & $\mathrm{n} / \mathrm{a}$ & 3.5 & 4.0 & 4.5 & 4.5 & 4.5 & 4.5 & 4.5 \\
\hline $\begin{array}{l}\text { Phase-in of deductions from CET1 (including amounts } \\
\text { exceeding the limit for deferred tax assets, mortgage } \\
\text { servicing rights, and financials) }\end{array}$ & $\mathrm{n} / \mathrm{a}$ & $\mathrm{n} / \mathrm{a}$ & $\mathrm{n} / \mathrm{a}$ & $\mathrm{n} / \mathrm{a}$ & $\mathrm{n} / \mathrm{a}$ & 20.0 & 40.0 & 60.0 & 80.0 & 100.0 & 100.0 \\
\hline Capital conservation buffer ${ }^{8}$ & $\mathrm{n} / \mathrm{a}$ & $\mathrm{n} / \mathrm{a}$ & $\mathrm{n} / \mathrm{a}$ & $\mathrm{n} / \mathrm{a}$ & $\mathrm{n} / \mathrm{a}$ & $\mathrm{n} / \mathrm{a}$ & $\mathrm{n} / \mathrm{a}$ & 0.625 & 1.25 & 1.875 & 2.5 \\
\hline $\begin{array}{l}\text { Countercyclical capital buffer for AA banks } \\
\text { (discretionary, } 0.0 \% \text { to } 2.5 \% \text { ) }\end{array}$ & $\mathrm{n} / \mathrm{a}$ & $\mathrm{n} / \mathrm{a}$ & $\mathrm{n} / \mathrm{a}$ & $\mathrm{n} / \mathrm{a}$ & $\mathrm{n} / \mathrm{a}$ & $\mathrm{n} / \mathrm{a}$ & $\mathrm{n} / \mathrm{a}$ & 0.625 & 1.25 & 1.875 & 2.5 \\
\hline Capital surcharge for GSIBs ${ }^{h}$ & $\mathrm{n} / \mathrm{a}$ & $\mathrm{n} / \mathrm{a}$ & $\mathrm{n} / \mathrm{a}$ & $\mathrm{n} / \mathrm{a}$ & $\mathrm{n} / \mathrm{a}$ & $\mathrm{n} / \mathrm{a}$ & $\mathrm{n} / \mathrm{a}$ & 0.25 to 4.5 & 0.50 to 4.5 & 0.75 to 4.5 & 1 to 4.5 \\
\hline $\begin{array}{l}\text { Capital instruments that no longer qualify as CET1 or } \\
\text { Tier } 1 \text { capital }^{i}\end{array}$ & $\mathrm{n} / \mathrm{a}$ & $\mathrm{n} / \mathrm{a}$ & $\mathrm{n} / \mathrm{a}$ & $\mathrm{n} / \mathrm{a}$ & $\mathrm{n} / \mathrm{a}$ & 80 & 60 & 40 & 20 & 0 & 0 \\
\hline
\end{tabular}

Note: $\mathrm{AA}=$ advanced approaches, CET1 = common equity Tier $1, \mathrm{GSIB}=$ global systemically important bank, IDI = insured depository institution, $\mathrm{n} / \mathrm{a}=$ not applicable NAA $=$ non-advanced approaches. ${ }^{a}$ Basel I was finalized in July 1988 and phased in over the period 1988-1992; it became fully effective in 1992 for all US banks. For the 1988-2010 period, see Federal Register 1989. ${ }^{b}$ US banking regulators published a final Basel II rule in December 2007 with a phase-in and it did not become effective until 1 April 2008. See Federal Register 2007. US federal banking agencies chose not to apply Basel II to all US banks, but only to the very largest, internationally active "core" US banks. ${ }^{c}$ US banking regulators published the final rule in June 2012 that became effective 1 January 2013, with revisions to certain capital requirements for trading positions and securitizations. See Federal Register 2012d. ${ }^{d}$ US banking regulators issued a final rule in July 2013 implementing Basel III; the rule became effective for AA banks, those with more than $\$ 250$ billion in assets or more than $\$ 10$ billion of on-balance-sheet foreign exposures, on 1 January 2014, and for NAA banks on 1 January 2015. See Federal Register 2013. The Collins Floor, required by the Dodd-Frank Act, established a firm's minimum capital ratio as the lower of its standardized-approach and advanced-approaches ratios, which include both minimum capital standards and the capital conservation buffer. ${ }^{e}$ The Tier 1 leverage ratio is the ratio of Tier 1 capital to on-balance-sheet assets less items deducted from Tier 1 capital. The leverage ratio applies to all banks, and must be at least 4 percent for an institution to be adequately capitalized and 5 percent to be well capitalized. The supplementary leverage ratio only applies to AA banks and is the ratio of Tier 1 capital to both on-balance-sheet and selected off-balance-sheet assets, or leverage exposure. ${ }^{f}$ Leverage ratio for AA bank holding companies is based on both on-balance-sheet and off-balance-sheet items, while only on-balance-sheet items are included for NAA bank holding companies. ${ }^{g}$ A bank's capital conservation buffer of 2.5 percent (on top of each risk-based ratio) will equal the lowest of the following three amounts: (1) a bank's CET1 ratio minus 4.5 percent; (2) a bank's Tier 1 risk-based capital ratio minus 6 percent; (3) a bank's total risk-based capital ratio minus 8 percent. Failure to meet these requirements results in restrictions on payouts of capital distributions and discretionary bonus payments to executives. ${ }^{h}$ GSIBs calculate their surcharges using two methods and use the higher of the two surcharges. The first method is based on the framework agreed to by the Basel Committee on Banking Supervision and considers a GSIB's size, interconnectedness, cross-jurisdictional activity, substitutability, and complexity. The second method uses similar inputs, but is calibrated to result in significantly higher surcharges and replaces substitutability with a measure of the firm's reliance on short-term wholesale funding. ${ }^{i}$ Basel III revised the regulatory capital treatment for Trust Securities, requiring them to be partially transitioned from Tier 1 capital into Tier 2 capital in 2014 and 2015, until fully excluded from Tier 1 capital in 2016, and partially transitioned and excluded from Tier 2 capital beginning in 2016. The exclusion from Tier 2 capital starts at 40 percent on January 1, 2016, increasing 10 percent each year until the full amount is excluded from Tier 2 capital beginning on 1 January 2022. Additional sources: Barth et al. 2012; Bank for International Settlements, Basel III: A Global Regulatory Framework for More Resilient Banks and Banking Systems (December 2010, rev. June 2011); European Parliament, US Implementation of Basel II: Final Rules Issued, but No Supervisory Approvals to Date (October 2011). 
Table 4 provides information on the various components of regulatory capital that are associated with the different required capital ratios under the US implementation of the Basel Capital Adequacy Standards. Different countries were free to implement the Basel Capital Adequacy Standards as they saw fit, given that Basel III provided guidelines rather than strict rules for the bank regulatory authorities in those countries implementing it. In the US, Basel III implementation brought major changes in the components of capital. In particular, banking regulators now consider the new capital measure, CET1 capital, to be the most loss-absorbing form of capital. The new emphasis on CET1 no doubt reflects the fact that, as the banking crisis emerged, market participants chose to focus more on capital measures that reflected loss-absorbing capital than on the official regulatory measures. CET1 includes qualifying common stock, retained earnings, certain accumulated other comprehensive income (AOCI) elements (if the bank does not make an AOCI opt-out election) plus or minus regulatory deductions or adjustments as appropriate, and qualifying CET1 minority interests. The banking regulators expect the majority of CET1 capital to be in the form of common voting shares. Non-advanced-approaches banks were allowed on their 31 March 2015 Call Report to make a permanent, onetime opt-out election, enabling them to calculate regulatory capital without AOCI. Such an election neutralizes the impact of unrealized gains or losses on available-for-sale bond portfolios in the context of regulatory capital levels. For banks that did not opt out, the AOCI adjustment to CET1 capital could have a significant impact on regulatory capital ratios if significant bond portfolio appreciation or depreciation occurs.

Unfortunately, this is not the end of the story. Fully describing what counts as regulatory capital demonstrates the complexity that is associated with calculating capital that complies with the regulatory requirements. Highlighting this complexity also reveals the difficulties that researchers must confront when they assess how changes in capital requirements affect bank behavior. For example, banks may respond differently to capital requirements depending on differences in both the level of existing capital and the composition of the existing components of that capital.

Banks must fully deduct several items from CET1 capital, such as goodwill, deferred tax assets that arise from a net operating loss and tax credit carry-forwards, other intangible assets (except for mortgage servicing assets), gains on sale of securitization exposures, and certain investments in another financial institution's capital instruments. Banks also must consider threshold deductions for three specific types of assets: mortgage servicing assets, deferred tax assets that are related to temporary timing differences, and significant investments in another unconsolidated financial institution's common stock. Generally, banks must deduct, by category, the amount of exposure to these types of assets that exceeds 10 percent of a base CET1 capital calculation. In addition, there is a 15 percent aggregate limit on these three threshold deduction items in CET1.

Additional non-CET1 capital includes qualifying noncumulative perpetual preferred stock, bank-issued Small Business Lending Fund and Troubled Asset Relief Program instruments that previously qualified for Tier 1 capital, and qualifying Tier 1 minority interests, less certain investments in other unconsolidated financial institutions' instruments that would otherwise qualify as additional Tier 1 capital. Tier 2 capital includes the allowance for loan and lease losses up to 1.25 percent of risk-weighted assets, qualifying preferred stock, subordinated debt, and qualifying Tier 2 minority interests, less any deductions in the Tier 2 instruments of an unconsolidated financial institution. Previous limits on term subordinated debt, limited-life preferred stock, and the amount of Tier 2 capital that can be included in total capital no longer apply. Non-qualifying capital instruments issued before 9 May 2010, by banks with less than $\$ 15$ billion in assets (as of 31 December 2009) are grandfathered, with the exception that grandfathered capital instruments cannot exceed 25 percent of Tier 1 capital. 
Table 4. A Timeline of US Regulatory Capital Components.

\begin{tabular}{|c|c|c|c|c|c|}
\hline \multirow{2}{*}{ Regulatory Capital Components } & \multicolumn{2}{|c|}{ Basel I ${ }^{a}$} & \multirow{2}{*}{$\begin{array}{c}\text { Basel II }^{b} \\
2011\end{array}$} & \multirow{2}{*}{$\begin{array}{c}\text { Basel II.5 }^{c} \\
2012\end{array}$} & \multirow{2}{*}{\begin{tabular}{|c|} 
Basel III $^{d}$ \\
2013 to as of 1 January 2019
\end{tabular}} \\
\hline & 1991-1992 & 1993-2010 & & & \\
\hline Tier 1 capital (old) & \multicolumn{4}{|c|}{$\begin{array}{c}\text { Common equity + preferred stock + qualifying hybrids + minority interests }- \text { (goodwill + } \\
\text { other intangibles, except for MSRs, PCCR, and DTAs) }\end{array}$} & $\mathrm{n} / \mathrm{a}$ \\
\hline Tier 2 capital (old) & \multicolumn{4}{|c|}{$\begin{array}{l}\text { Undisclosed reserves + assets revaluation reserves + general provisions/general loan loss } \\
\text { reserves + preferred stock + qualifying hybrids + subordinated debt }\end{array}$} & $\mathrm{n} / \mathrm{a}$ \\
\hline Tier 3 capital (old) & $\mathrm{n} / \mathrm{a}$ & $\mathrm{n} / \mathrm{a}$ & \multicolumn{2}{|c|}{$\begin{array}{l}\text { Short-term subordinated debt, solely to } \\
\text { support the market risks in the trading book }\end{array}$} & $\mathrm{n} / \mathrm{a}$ \\
\hline CET1, going-concern capital (new) & $\mathrm{n} / \mathrm{a}$ & $\mathrm{n} / \mathrm{a}$ & $\mathrm{n} / \mathrm{a}$ & $\mathrm{n} / \mathrm{a}$ & $\begin{array}{l}\text { Common stock and retained earnings } \pm \text { limited accumulated other } \\
\text { comprehensive income items for opt-out banks (or accumulated } \\
\text { other comprehensive income for non-opt-out and } \\
\text { advanced-approaches banks) } \pm \text { deductions and adjustments + } \\
\text { qualifying CET1 minority interest - (goodwill + deferred tax assets + } \\
\text { other intangibles) }\end{array}$ \\
\hline $\begin{array}{l}\text { Additional Tier } 1 \text { capital (AT1), } \\
\text { going-concern capital (new) }\end{array}$ & $\mathrm{n} / \mathrm{a}$ & $\mathrm{n} / \mathrm{a}$ & $\mathrm{n} / \mathrm{a}$ & $\mathrm{n} / \mathrm{a}$ & $\begin{array}{l}\text { Noncumulative perpetual preferred stock, including surplus + SBLF } \\
\text { \& TARP (bank issued) + qualifying Tier } 1 \text { minority interest - certain } \\
\text { investments in financial institutions }\end{array}$ \\
\hline Tier 2 capital, gone-concern capital (new) & $\mathrm{n} / \mathrm{a}$ & $\mathrm{n} / \mathrm{a}$ & $\mathrm{n} / \mathrm{a}$ & $\mathrm{n} / \mathrm{a}$ & $\begin{array}{c}\text { Limited allowance for loan and lease losses + preferred stock and } \\
\text { subordinated debt }+ \text { qualifying Tier } 2 \text { minority interest }- \text { Tier } 2 \\
\text { investments in financial institutions }\end{array}$ \\
\hline $\begin{array}{l}\text { Total capital (CET1 capital + AT1, or Tier } 1 \\
\text { capital, + Tier } 2 \text { capital) }\end{array}$ & $\mathrm{n} / \mathrm{a}$ & $\mathrm{n} / \mathrm{a}$ & $\mathrm{n} / \mathrm{a}$ & $\mathrm{n} / \mathrm{a}$ & $\begin{array}{l}\text { All of the above items with limits eliminated on subordinated debt } \\
\text { and limited-life preferred stock in Tier } 2 \text { capital and no limit on Tier } 2 \\
\text { capital }\end{array}$ \\
\hline Capital conservation buffer (CCB) (new) & $\mathrm{n} / \mathrm{a}$ & $\mathrm{n} / \mathrm{a}$ & $\mathrm{n} / \mathrm{a}$ & $\mathrm{n} / \mathrm{a}$ & $\begin{array}{c}\text { CET1 (CCB ratio must be in excess of CET1, Tier } 1 \text { and total capital } \\
\text { ratios by at least } 2.5 \% \text { to avoid limits on capital distributions and } \\
\text { certain discretionary bonus payments) }\end{array}$ \\
\hline Countercyclical capital buffer (new) & $\mathrm{n} / \mathrm{a}$ & $\mathrm{n} / \mathrm{a}$ & $\mathrm{n} / \mathrm{a}$ & $\mathrm{n} / \mathrm{a}$ & CET1 \\
\hline $\begin{array}{l}\text { Capital surcharge for global systemically } \\
\text { important banks (new) }\end{array}$ & $\mathrm{n} / \mathrm{a}$ & $\mathrm{n} / \mathrm{a}$ & $\mathrm{n} / \mathrm{a}$ & $\mathrm{n} / \mathrm{a}$ & CET1 \\
\hline Leverage capital & Tier 1 (old) & Tier 1 (old) & Tier 1 (old) & Tier 1 (old) & CET1 + AT1 (new Tier 1) \\
\hline
\end{tabular}
Note: CET1 $=$ common equity Tier $1, \mathrm{DTA}=$ deferred tax assets, MSR $=$ mortgage servicing rights, $\mathrm{n} / \mathrm{a}=$ not applicable, PCCR $=$ purchased credit card receivables, SBLF $=$ small business
lending fund, TARP $=$ troubled asset relief program. ${ }^{a}$ See Federal Register 1989. ${ }^{b}$ See Federal Register 2007. ${ }^{c}$ See Federal Register $2012 \mathrm{~d} .{ }^{d}$ See Federal Register $2013 .{ }^{e}$ For the rule introducing Tier 3 capital, see Federal Register 1996. 
In assessing the financial condition of a bank, the denominator in the risk-based capital ratio is as important as the numerator, if not more so. As noted earlier, Basel I was the first capital standard based on RWAs. Then, in response to the growing importance of trading activities of large banks, Basel I was amended in 1996 to expand capital requirements to include capital charges for market risk. Then again, Basel II.5 added capital charges for certain types of trading activities by changing the calculation of risk weights for the trading book. More generally, as compared to Basel I, Basel II and II.5 provided for more detailed calculations of the risk-sensitivity of banks. Indeed, according to Andrew Haldane, "[For] a large, representative bank using an advanced internal set of models to calibrate capital... [its] number of risk buckets has increased from around seven under Basel I to, on a conservative estimate, over 200,000 under Basel II". ${ }^{13}$

In Basel III, there are two general approaches to RWAs. The standardized approach is generally designed for community banks, while the advanced approach is used by larger, more complex banks. The standardized approach applies to BHCs with $\$ 500$ million or more in consolidated assets. Risk-weighted assets consist of credit-risk RWAs plus market-risk RWAs (if applicable). Credit-risk RWAs include risk-weighted assets for general credit risk, cleared transactions, default fund contributions, unsettled transactions, securitization exposures, and equity exposures. General credit risk involves the consideration of general risk weights, off-balance-sheet exposures, over-the-counter derivative contracts, cleared transactions, guarantees, credit derivatives, and collateralized transactions. Since the introduction of the risk-weighting system in the United States in the early 1990s, the general process of risk weighting assets has not changed. However, the movement from Basel I to Basel III has brought several specific changes in risk weights.

Table 5 shows that the standardized approach for Basel III involves risk weights other than the $0,20,50$, and 100 percent categories that were initially implemented for Basel I. The Basel III risk-weighting categories allow for more detailed risk weights, and the weights now range from a low of 0 to a high of 150 percent. The risk weight for exposures to, and portions of exposures that are directly and unconditionally guaranteed by, the US government, its agencies, and the Federal Reserve is zero percent. The risk weight for high-volatility commercial real estate loans is 150 percent, up from 100 percent under Basel I. Section 939 of the Dodd-Frank Act directs the banking regulators to remove regulatory references to external credit ratings from regulations. ${ }^{14}$ This provision was a legislative response to the failure of the ratings to adequately indicate the riskiness of various securities. That failure affected the ability to assess the riskiness of banks and other entities leading up to the 2007-2009 financial crisis.

13 See Haldane (2011), p. 2.

14 By contrast, the Federal Reserve, Federal Deposit Insurance Corporation, and Office of the Comptroller of the Currency finalized a joint rulemaking known as the "Recourse Rule" on 29 November 2001. See Office of the Comptroller of the Currency, Board of Governors of the Federal Reserve System, Federal Deposit Insurance Corporation, and Office of Thrift Supervision, Federal Register 2001. The Recourse Rule set capital requirements for private label asset- and mortgage-backed securities and other positions in securitization transactions (except for credit-enhancing interest-only strips) according to their relative risk using credit ratings from rating agencies to measure the level of risk. As Erel et al. (2014, p. 411) note, after this change "a bank that made subprime loans was better off holding them on its books as securities backed by these loans than holding the loans directly". As they point out, the regulatory capital charge became a function of the securities' credit ratings rather than their asset class. Miller (2018) shows that the largest banking organizations with subsidiaries that commented on the regulation during the notice and comment period began increasing their holdings of the highly-rated, private label securitization tranches once the rule went into effect, and that those that held more after 2008 on average experienced greater subsequent rises in default risk and stock price volatility. 
Table 5. Basel I and Basel III: US Risk Weights for On-Balance-Sheet and Off-Balance-Sheet Items for the Standardized Approach.

\begin{tabular}{|c|c|c|c|c|}
\hline Selected Items & Existing Basel I-Based Risk Weights ${ }^{a}$ & \multicolumn{3}{|c|}{ US Basel III Final Rule Standardized Risk Weights ${ }^{b}$} \\
\hline Cash & $0 \%$ & $0 \%$ & & \\
\hline $\begin{array}{l}\text { Exposures to, and portions of exposures that are } \\
\text { directly and unconditionally guaranteed by, the US } \\
\text { government, its agencies, and the Federal Reserve }\end{array}$ & $0 \%$ & $0 \%$ & & \\
\hline $\begin{array}{l}\text { Exposures to foreign governments and their } \\
\text { central banks }\end{array}$ & $\begin{array}{l}0 \% \text { for direct and unconditional claims on } \\
\text { Organisation for Economic Co-operation and } \\
\text { Development (OECD) governments } \\
20 \% \text { for conditional claims on OECD governments } \\
100 \% \text { for claims on non-OECD governments that } \\
\text { entail some degree of transfer risk }\end{array}$ & $\begin{array}{l}\text { Risk weight depends on the sovereign's OECD } \\
\text { country risk classification (CRC) } \\
\text { Sovereign CRC } \\
\text { OECD member with no CRC } \\
\text { Non-OECD member with no CRC } \\
\text { Sovereign default }\end{array}$ & $\begin{array}{l}0-1 \\
2 \\
3 \\
4-6 \\
7\end{array}$ & $\begin{array}{l}\text { Risk weight } \\
0 \% \\
20 \% \\
50 \% \\
100 \% \\
150 \% \\
0 \% \\
100 \% \\
150 \%\end{array}$ \\
\hline $\begin{array}{l}\text { Exposures to US government-sponsored } \\
\text { enterprises }\end{array}$ & $20 \%$ & $20 \%$ & & \\
\hline \multirow{2}{*}{$\begin{array}{l}\text { Exposures to US public-sector entities, including } \\
\text { US states and municipalities }\end{array}$} & $20 \%$ for general obligations & $20 \%$ for general obligations & & \\
\hline & $50 \%$ for revenue obligations & $50 \%$ for revenue obligations & & \\
\hline Exposures to foreign public-sector entities & $\begin{array}{l}20 \% \text { for general obligations of states and political } \\
\text { subdivisions of OECD countries } \\
50 \% \text { for revenue obligations of states and political } \\
\text { subdivisions of OECD countries } \\
100 \% \text { for all obligations of states and political } \\
\text { subdivisions of non-OECD countries }\end{array}$ & $\begin{array}{l}\text { Risk weight depends on the home country's CRC } \\
\text { Sovereign CRC } \\
\text { OECD member with no CRC } \\
\text { Non-OECD member with no CRC } \\
\text { Sovereign default } \\
\text { Sovereign CRC } \\
\text { OECD member with no CRC } \\
\text { Non-OECD member with no CRC } \\
\text { Sovereign default }\end{array}$ & $\begin{array}{l}0-1 \\
2 \\
3 \\
4-7\end{array}$ & $\begin{array}{l}\text { Risk weight for general obligations } \\
20 \% \\
50 \% \\
100 \% \\
150 \% \\
20 \% \\
100 \% \\
150 \% \\
\text { Risk weight for revenue obligations } \\
50 \% \\
100 \% \\
150 \% \\
50 \% \\
100 \% \\
150 \%\end{array}$ \\
\hline $\begin{array}{l}\text { Exposures to US depository institutions and credit } \\
\text { unions }\end{array}$ & $20 \%$ & $20 \%$ & & \\
\hline
\end{tabular}


Table 5. Cont.

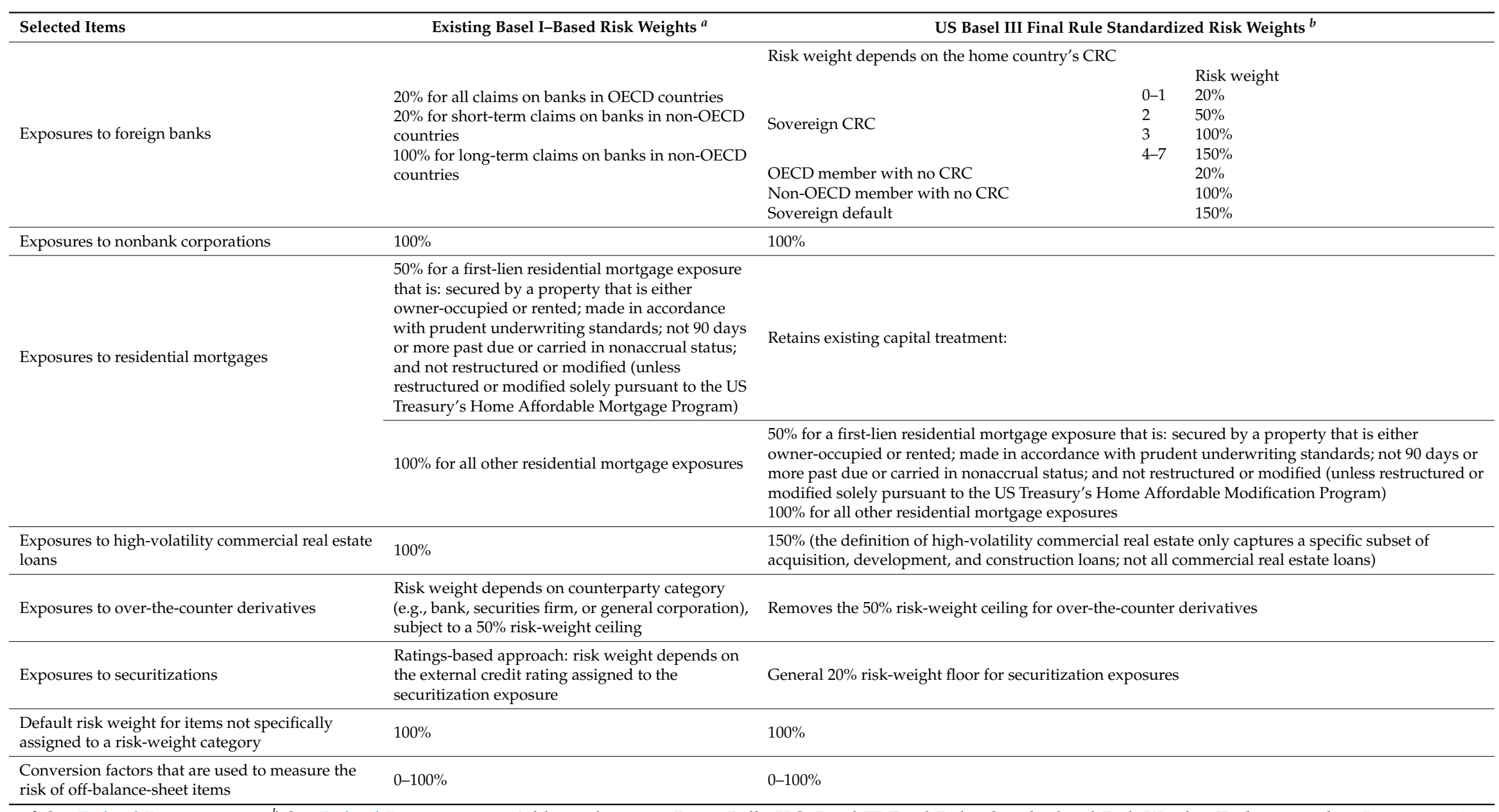

${ }^{a}$ See Federal Register 1989. ${ }^{b}$ See Federal Register 2013. Additional source: Davis Polk, U.S. Basel III Final Rule: Standardized Risk Weights Tool, accessed 27 January 2017, http://www.usbasel3.com/tool/. 
The advanced approach under Basel III applies to BHCs with consolidated assets that are greater than $\$ 250$ billion or balance-sheet foreign exposures greater than $\$ 10$ billion. These banks are required to determine compliance with minimum capital requirements based on the lower of the capital ratios that were calculated under the standardized and advanced approaches. Using the advanced approach, risk-weighted assets are the sum of credit-risk RWAs, market-risk RWAs (if applicable), and operational RWAs. Credit-risk RWAs include risk-weighted assets for general credit risk, securitization exposures, and equity exposures. General credit risk refers to wholesale and retail RWAs, as well as the counterparty credit risk of repo-style transactions, eligible margin loans, over-the-counter derivative contracts, cleared transactions, unsettled transactions, guarantees, and credit derivatives. ${ }^{15}$ Market-risk RWAs-which apply only to BHCs that have aggregate trading assets and liabilities equal to either 10 percent or more of total assets or at least $\$ 1$ billion—are based on the following risk categories: interest rate, credit spread, equity price, foreign exchange, and commodity price. Operational-risk RWAs have the same basic RWA formula as that of market risk.

\subsection{How US Bank Capital Regulation Has Grown Increasingly Complex Since 1970}

Herring $(2016,2018)$ argues that 75 percent of the various capital requirements for US GSIBs could be eliminated without weakening capital regulation, and offers that as evidence of the growing complexity of US capital requirements. An alternative way to view the growing complexity embodied in US capital adequacy standards comes from RegData 3.1 (see McLaughlin and Sherouse (2018)). The database provides counts of the number of regulatory restrictions in the CFR, which include words, such as "may not", "must", "required", "shall", and "prohibited". More restrictions that are embodied in the CFR in principle means that banking organizations must spend more resources on compliance. In the CFR, Title 12 concerns banks and banking. Parts 1-199 concern the Office of the Comptroller of the Currency (OCC), parts 200-299 concern the Federal Reserve System (FRS) and parts 300-399 concern the Federal Deposit Insurance Corporation (FDIC) ${ }^{16}$ The parts of the CFR that concern commercial bank capital requirements in Title 12 include "Part 3-Capital Adequacy Standards", "Part 217-Capital Adequacy of BHCs, S\&L Holding Companies, and State Member Banks" for the FRS and "Part 324-Capital Adequacy of FDIC-Supervised Institutions" and "Part 325-Capital Maintenance" for the FDIC. We can present measures of the rising complexity of bank capital requirements by dividing the total number of regulatory restrictions that concern bank capital by the total number of regulatory restrictions, for each agency.

Figure 1 depicts the fraction of regulatory restrictions for the FDIC, OCC and Federal Reserve that concern capital requirements since 1970. The figure shows that the fraction of restrictions that concern bank capital for the FDIC and OCC has increased greatly relative to what existed under Basel I, and now equals nearly 25 percent. For the Federal Reserve, almost all of the regulatory restrictions have come since Basel III, and by 2017, exceeded 10 percent. ${ }^{17}$

As a suggestive exercise, we estimate how capital requirements contribute to overall regulatory complexity by agency by applying Mora and Reggio (2017) fully flexible approach to estimating average treatment effects. The idea is to estimate how many additional restrictions or word counts are on average generated by regulatory capital requirements.

15 Under US generally accepted accounting principles (GAAP), banks are allowed to report their derivatives on a net basis. Under international financial reporting standards (IFRS), European banks are generally required to report their derivatives on a gross basis. This leads to a substantial decrease in the size of the balance sheet for large US banks as compared to large European banks.

16 The OCC regulates banks with a national charter. The Federal Reserve regulates bank and financial holding companies, as well as banks with state charters that are Federal Reserve member banks. The FDIC regulates banks with state charters that are not Federal Reserve member banks.

17 We exclude "Part 226-Truth In Lending" from the measure for FRS regulatory restrictions, given that that part generates by far the largest fraction of regulatory restrictions for the FRS, but does not concern the other regulators. If we include that part, the fraction falls to about 8 percent by the end of the sample. 


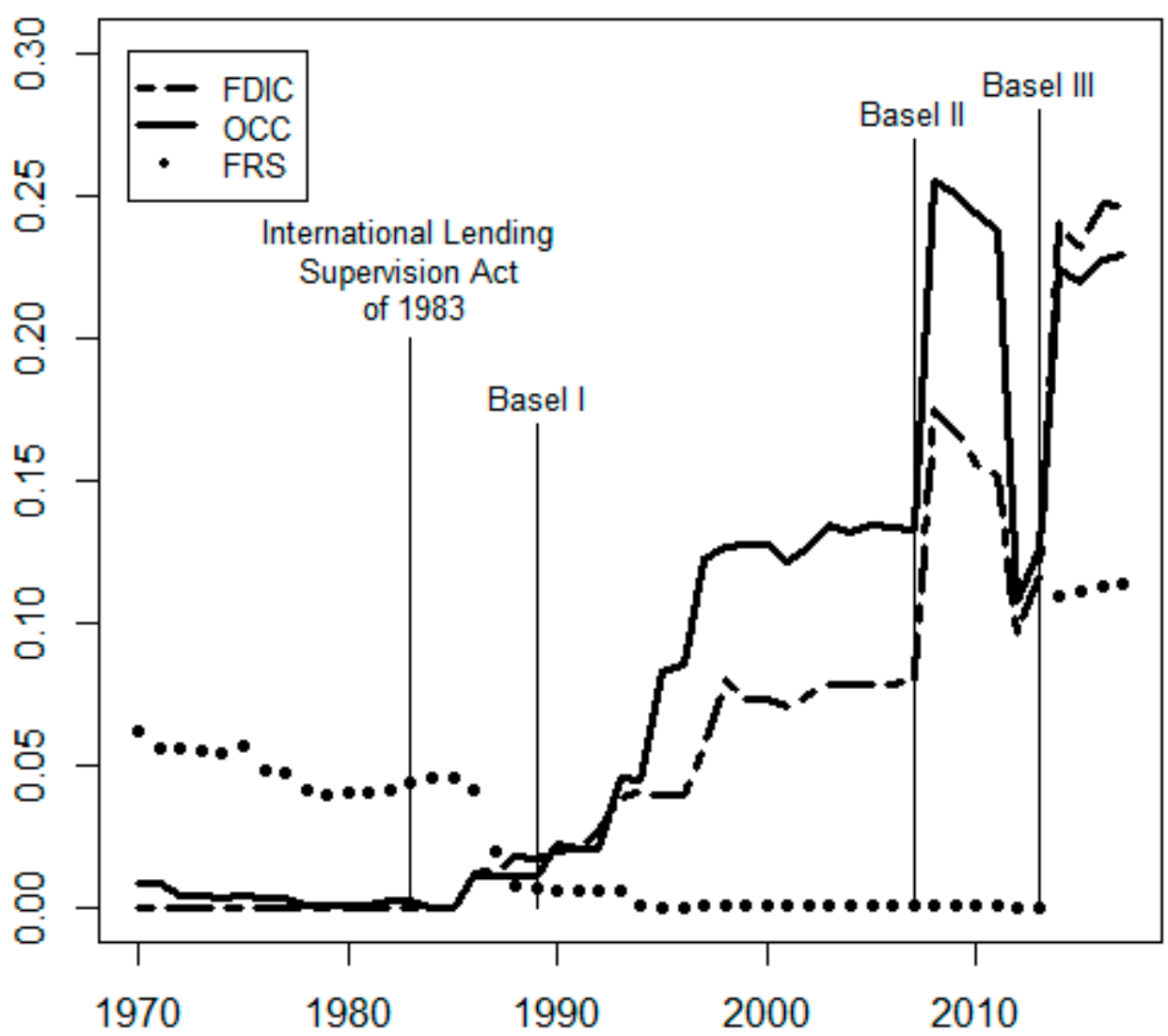

Figure 1. The Fraction of Regulatory Restrictions Arising from Bank Capital Requirements, 1970-2017.

Mora and Reggio (2017) show that, if the trends for the treatment and control groups are the same, the appropriate estimator for the average treatment effect for the difference-in-differences estimator under the parallel paths assumption yields the same treatment effects as the difference in double-differences estimator under the parallel growths assumption. This no longer holds if the pre-treatment dynamics for the treatment and control groups differ. They also propose a test for equal pre-treatment dynamics.

The outcome variable here is either the total number of regulatory restrictions or total word counts in the CFR, by year, for the OCC and FDIC; we exclude the Federal Reserve given that there were many years when Part 217 generated no regulatory restrictions. As a treatment variable, we use a dummy variable that equals one if the CFR part equals 3 for the OCC, or 324 or 325 for the FDIC, and equals zero otherwise. ${ }^{18}$ The assumption is that restrictions (or word counts) in the parts of the CFR that concern capital contribute to the total number of restrictions (or word counts), and not vice versa. As a post-treatment period, we use the period starting in 1989, when Basel I was finalized by US regulators. As an alternative, we estimate similar average treatment effects after replacing total regulatory restrictions with total word counts. Given that we do not reject the null hypothesis of

18 The specification used to estimate the average treatment effects is, $y_{p t}=\beta_{0}+\sum_{\tau=2}^{T} \delta_{\tau} d_{\tau, t}+\beta_{1}$ Treat $_{p t}+\sum_{\tau=2}^{T} \beta_{\tau} d_{\tau, t}$ Treat $_{p t}+$ $\varepsilon_{i t}$, where $\beta_{\tau}$ is the coefficient estimate of interest. We estimate the model with standard errors clustered by CFR part. The sample used to estimate the models for the OCC have 1285 observations and 91 parts, and the R-Squared for the model applied to restrictions (word counts) equals 0.29 (0.45). The sample used to estimate the models for the FDIC have 1513 observations and 59 parts, and the R-Squared for the model applied to restrictions (word counts) equals 0.12 ( 0.21 ). While Mora and Reggio's method does not include fixed effects, the trends in the time dummy-treatment variable interaction terms whether or not we include fixed effects are often visually indistinguishable. In addition, the median difference between pooled OLS and fixed effects estimates as a fraction of the fixed effects interaction term estimates for OCC restrictions or word counts equals 0.01 and for FDIC restrictions or word counts equals 0.10 and 0.03 , respectively. 
equal pre-treatment dynamics, we report results for the post-treatment effects assuming parallel paths, together with the 95 percent confidence interval, from 1989-2017 in Figure $2 .{ }^{19}$

\section{OCC}

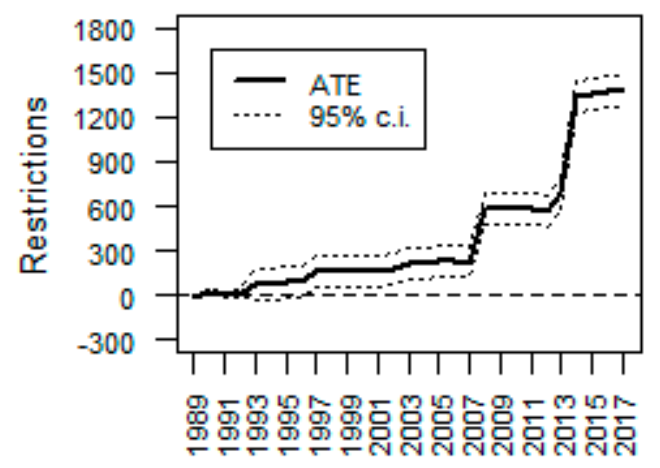

OCC

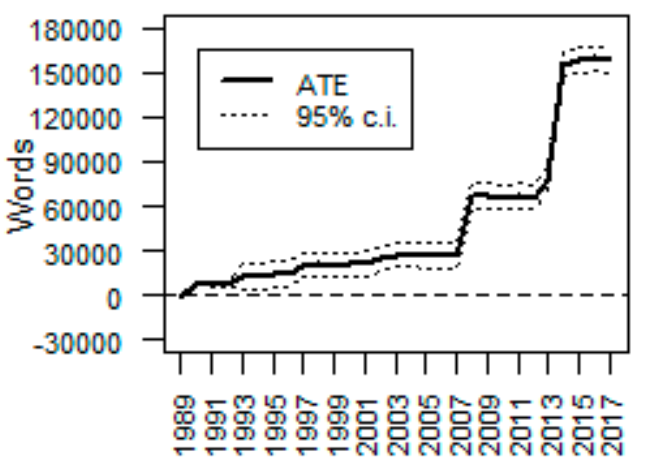

FDIC

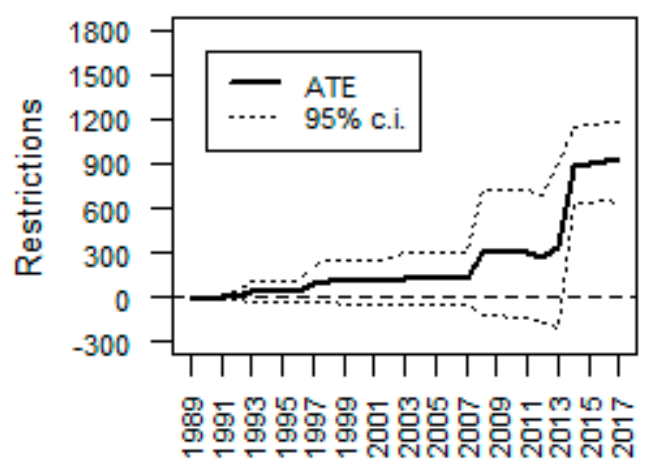

FDIC

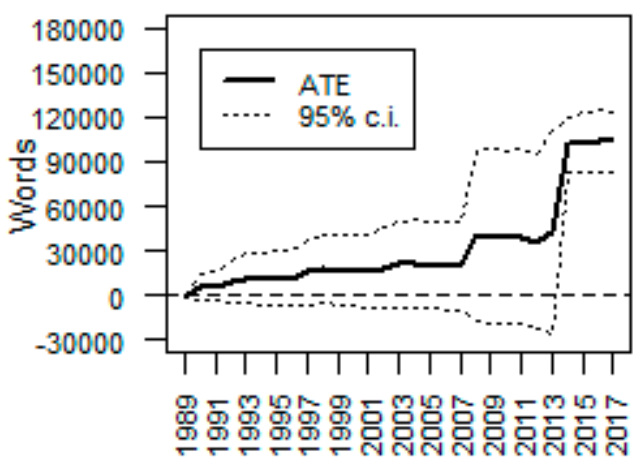

Figure 2. Average Treatment Effects of Bank Capital Requirements on Regulatory Restrictions and Word Counts Since Basel I, 1989-2017.

The figure shows that the CFR parts that concern capital requirements on average generate a substantial number of restrictions relative to all other parts. For instance, Part 3, on average, generated roughly 600 (1300) more regulatory restrictions and 70,000 $(150,000)$ extra words than other parts under Basel II after 2007 (Basel III after 2013). For comparison, the other parts of the CFR for the OCC on average generated 55 restrictions (7000 words) after 2007 and over 65 restrictions (7000 words) after 2013. Basel II and Similarly, Parts 324 and 325 for the FDIC on average generated about 300 (900) more regulatory restrictions and 40,000 (100,000) extra words than other parts under Basel II after 2007 (Basel III after 2013). For comparison, the other parts of the CFR for the FDIC on average generated about 60 restrictions (6000-7000 words) after 2007 and over 100 restrictions (11,000 words) after 2013.

Beyond the added compliance costs, regulatory complexity also can have unintended consequences including opportunities for regulatory arbitrage, which have been observed by academics long before the 2007-2009 crisis (e.g., Merton (1995); Jones (2000); and, Brealey (2006)). Although the risk weights

19 For OCC restrictions (word counts) the $p$-value for tests of the hypothesis of common pre-treatment dynamics equals 0.62 (0.21). For FDIC restrictions (word counts) the $p$-value for tests of the hypothesis of common pre-treatment dynamics equals $0.17(0.47)$. Therefore, we report the parallel paths rather than parallel growth results. 
have become much more complex since the introduction of Basel I, the basic framework-setting minimum capital requirements as a fraction of RWAs with risk weights assigned to asset categories-has remained the same. At the same time, Acharya et al. (2014, p. 38) argue that "risk weights are flawed measures of bank risks cross-sectionally as banks game their risk-weighted assets (cherry-pick on risky but low risk-weight assets) to meet regulatory capital requirements, which does not necessarily reduce economic leverage". Other studies find that non-risk-based measures of capital better predict bank stock returns or bank risk than risk-based measures (see Demirguc-Kunt et al. (2013); Hogan (2015); and, Hogan and Meredith (2016)). Moreover, Flannery (2014) observes that banks satisfied regulatory capital requirements, which rely on book values, while market valuations of capital plunged well below book values during the crisis; we examine such problems in more detail next.

\section{Beyond US Basel Capital Regulations}

\subsection{US Prompt Corrective Action Requirements}

In addition to the implementation of the Basel Capital Accords, US banks are subject to PCA requirements. The PCA regulatory regime was established pursuant to the Federal Deposit Insurance Corporation Improvement Act of December 1991 (FDICIA) and it became effective in December 1992. ${ }^{20}$ The FDICIA requires insured depository institutions (IDIs) and federal banking regulators to take "prompt corrective action" to resolve capital deficiencies at IDIs.

Table 6 shows the old and new capital ratios that are associated with the different categories calling for the various regulatory actions to resolve capital deficiencies. The major change is that a stricter measure of capital (CET1) than the previous Tier 1 capital ratio was introduced by eliminating some components that had previously counted as capital. In addition, the associated ratios for the new measure as compared to the previous measure have been increased, at least for Tier 1 capital. The new PCA ratios became effective on 1 January 2015, for all banks. As Table 6 indicates, banks are placed into one of five categories depending on their leverage and risk-based capital (RBC) ratios. Well-capitalized banks are those banks that meet all five thresholds and are not subject to formal action to maintain a specific capital level. Banks that are less than well-capitalized are subject to increasingly stringent provisions to resolve capital deficiencies as their capital ratios decline. The regulatory authorities of banks that become critically undercapitalized must within 90 days appoint a receiver or take other such actions that would better serve the purposes of PCA (and review such actions every 90 days). Lastly, the standards for determining whether a BHC is well-capitalized are not established.

What has not changed is the "critically undercapitalized" category. This may continue to pose challenges to the effectiveness of PCA. Balla et al. (2017) show that the FDIC has been adhering to the PCA in the sense that the average amount of tangible capital relative to assets for failed banks increased from -2 percent in the 1986-1992 period to 1.4 percent in the 2007-2013 period. However, they also show that the costs of closure were higher during the latter period. Cole and White (2017) report that the FDIC estimated that the cost of closure during the most recent crisis equaled 23.8 percent of total assets and estimated that about 37 percent of the $\$ 49.8$ billion costs of closure was due to delaying closure of weak banks. Cole and White (2017) suggest this may reflect problems in generally accepted accounting principles (GAAP) and also that a more effective PCA reform might focus on increasing provisions, so that banks do not overstate the book value of their capital or including non-performing assets in capital ratios.

20 For the Federal Deposit Insurance Corporation Improvement Act (FDICIA) of 1991, see Public Law 102-242, 105 Stat. 2236. See also Balla et al. (2017) and Cole and White (2017) for a discussion. 
Table 6. US Prompt Corrective Action (PCA), Old and New.

\begin{tabular}{|c|c|c|c|c|c|c|c|c|}
\hline \multirow[b]{2}{*}{ PCA Threshold } & \multicolumn{3}{|c|}{ Old PCA Categories (IDIs) ${ }^{a}$} & \multicolumn{5}{|c|}{ New PCA Categories (IDIs) ${ }^{b}$} \\
\hline & Tier 1 Leverage (\%) & Tier 1 RBC (\%) & Total RBC (\%) & $\begin{array}{c}\text { Tier } 1 \text { Leverage } \\
\text { (\%) }\end{array}$ & $\begin{array}{c}\text { Tier } 1 \text { Capital } \\
\text { (\%) }\end{array}$ & $\begin{array}{c}\text { Common } \\
\text { Equity Tier } 1 \\
\text { RBC (\%) }\end{array}$ & Total RBC (\%) & $\begin{array}{l}\text { Supplementary } \\
\text { Leverage Ratio } \\
\text { (AA/IDIs only) }\end{array}$ \\
\hline Well capitalized & $\geq 5.0$ & $\geq 6.0$ & $\geq 10.0$ & $\geq 5.0$ & $\geq 8$ & $\geq 6.5$ & $\geq 10.0$ & $\mathrm{n} / \mathrm{a}$ \\
\hline Adequately capitalized & $\geq 4.0$ & $\geq 4.0$ & $\geq 8.0$ & $\geq 4.0$ & $\geq 6$ & $\geq 4.5$ & $\geq 8.0$ & $\geq 3$ \\
\hline Undercapitalized & $<4.0$ & $<4.0$ & $<8.0$ & $<4.0$ & $<6$ & $<4.5$ & $<8.0$ & $<3$ \\
\hline $\begin{array}{l}\text { Significantly } \\
\text { undercapitalized }\end{array}$ & $<3.0$ & $<3.0$ & $<6.0$ & $<3.0$ & $<4$ & $<3.0$ & $<6.0$ & $\mathrm{n} / \mathrm{a}$ \\
\hline Critically undercapitalized & \multicolumn{7}{|c|}{ tangible equity $/$ total assets $\leq 2 \%$} & $\mathrm{n} / \mathrm{a}$ \\
\hline
\end{tabular}

Note: $\mathrm{AA}=$ advanced approaches, IDI = insured depository institution, $\mathrm{n} / \mathrm{a}=$ not applicable, $\mathrm{RBC}=$ risk-based capital. Tangible equity is Tier 1 capital plus non-Tier 1 perpetual preferred stock. Also, the supplementary leverage ratio becomes effective 1 January 2018. ${ }^{a}$ See Federal Register 1992. ${ }^{b}$ See Federal Register 2013. Additional source: Federal Deposit Insurance Corporation 2014, Regulatory Capital Interim Final Rule, https:/ / fdic.gov/regulations/resources/director/RegCapIntFinalRule.pdf. 


\subsection{US Capital Planning and Stress Tests}

Supervisory stress testing by banking regulators gained prominence during the banking crisis of 2007-2009. In particular, in 2009, banking supervisors conducted the Supervisory Capital Assessment Program (SCAP) to assess the largest bank holding companies' capital positions. SCAP presented two hypothetical macroeconomic scenarios, including one that was more adverse than what was expected for the US economy, for BHCs to use in estimating the impact on capital. The Federal Reserve publicly reported that 10 of the 19 BHCs that were included in SCAP did not meet the capital adequacy requirements under the adverse macroeconomic scenario. As a result, these BHCs were collectively required to add $\$ 185$ billion in capital by the end of 2010 (Office of the Inspector General 2015).

Section 165(i) of the Dodd-Frank Act mandated an annual assessment by the Federal Reserve of BHCs with $\$ 50$ billion or more in total consolidated assets, as well as smaller BHCs and nonbank financial institutions that are regulated by the Federal Reserve. This annual assessment includes two related programs: the Comprehensive Capital Analysis and Review (CCAR) and supervisory stress testing (DFAST). ${ }^{21}$ These annual stress tests look at whether the BHCs have effective capital adequacy processes and sufficient capital to absorb losses during stressful conditions, while meeting obligations to creditors and counterparties and continuing to serve as credit intermediaries.

In late 2010, the Federal Reserve-acting in part in response to the statute-initiated the CCAR exercise. As part of the exercise, the Federal Reserve evaluates institutions' capital adequacy, their internal capital adequacy assessment processes, and their individual plans to make capital distributions, such as dividend payments or stock repurchases. More specifically, CCAR specifies four mandatory elements of a capital plan: (1) an assessment of the expected uses and sources of capital over the planning horizon that reflects the BHC's size, complexity, risk profile, and scope of operations, assuming both expected and stressful conditions; (2) a detailed description of the BHC's process for assessing capital adequacy; (3) the BHC's capital policy; and, (4) a discussion of any baseline changes to the BHC's business plan that are likely to have a material impact on the BHC's capital adequacy or liquidity. ${ }^{22}$

The Federal Reserve has conducted CCAR annually since its inception in 2010 for the largest BHCs. For the CCAR 2015 exercise, the Federal Reserve issued instructions on 17 October 2014, and received capital plans from 31 BHCs on 5 January 2015. Table 7 shows the banks participating in CCAR in 2015 as well as the required capital ratios. The 31 BHCs that are part of this CCAR held more than 80 percent of the total assets of all US BHCs, or $\$ 14$ trillion as of the fourth quarter of 2014. The Federal Reserve reported that, in 2015, for the first time, no participating bank fell below the quantitative benchmarks that must be met in CCAR after some BHCs made onetime downward adjustments to their planned capital distributions or redemptions. However, the Federal Reserve did object to Santander's CCAR 2015 capital plan on qualitative grounds because of widespread and critical deficiencies across the BHC's capital planning processes. The Federal Reserve also objected on qualitative grounds to the capital plan of Deutsche Bank Trust Corporation because of numerous and significant deficiencies across its risk-identification, measurement, and aggregation processes; approaches to loss and revenue projection; and, internal controls (Board of Governors of the Federal Reserve System 2015).

21 For the final rule for supervisory guidance on banking organizations with greater than $\$ 10$ billion in total consolidated assets, see Federal Register 2012f. For the OCC's annual stress test final rule, see Federal Register 2012c. For the FDIC's annual stress test final rule, see Federal Register 2012b. For the Fed's final rule for supervisory and company-run stress tests, see Federal Register 2012e. For the Fed's final rule for company-run stress tests for banking organizations with greater than $\$ 10$ billion in total consolidated assets, see Federal Register 2012a.

22 See Board of Governors of the Federal Reserve System (2012). 
Table 7. Comprehensive Capital Analysis and Review (CCAR) 2015 Bank Holding Companies (BHCs) and Applicable Minimum Capital Ratios.

\begin{tabular}{|c|c|c|c|}
\hline \multicolumn{4}{|c|}{ Advanced-Approaches BHCs in CCAR 2015} \\
\hline $\begin{array}{c}\text { American Express } \\
\text { Company (NYC, NY, } \\
\text { USA) }\end{array}$ & $\begin{array}{c}\text { Bank of America } \\
\text { Corporation (CHARLOTTE, } \\
\text { NC, USA) }\end{array}$ & $\begin{array}{c}\text { Bank of New York Mellon } \\
\text { Corporation (NYC, NY, } \\
\text { USA) }\end{array}$ & $\begin{array}{c}\text { Capital One Financial } \\
\text { Corporation (NYC, NY, } \\
\text { USA) }\end{array}$ \\
\hline $\begin{array}{c}\text { Citigroup Inc. (NYC, NY, } \\
\text { USA) }\end{array}$ & $\begin{array}{l}\text { Goldman Sachs Group Inc. } \\
\text { (NYC, NY, USA) }\end{array}$ & $\begin{array}{l}\text { HSBC North America } \\
\text { Holdings Inc. (NYC, NY, } \\
\text { USA) }\end{array}$ & $\begin{array}{l}\text { JPMorgan Chase \& Co. } \\
\text { (NYC, NY, USA) }\end{array}$ \\
\hline $\begin{array}{c}\text { Morgan Stanley (NYC, } \\
\text { NY, USA) }\end{array}$ & $\begin{array}{l}\text { Northern Trust Corporation } \\
\text { (CHICAGO, IL, USA) }\end{array}$ & $\begin{array}{c}\text { PNC Financial Services } \\
\text { Group Inc. (PITTSBURGH, } \\
\text { PA USA) }\end{array}$ & $\begin{array}{l}\text { State Street Corporation } \\
\text { (BOSTON, MA, USA) }\end{array}$ \\
\hline $\begin{array}{c}\text { U.S. Bancorp } \\
\text { (PORTLAND, OR, USA) }\end{array}$ & $\begin{array}{l}\text { Wells Fargo \& Co. (SAN } \\
\text { FRANCISCO, CA, USA) }\end{array}$ & & \\
\hline \multicolumn{4}{|c|}{ Other BHCs for CCAR 2015} \\
\hline $\begin{array}{l}\text { Ally Financial Inc. } \\
\text { (DETROIT, MI, USA) }\end{array}$ & $\begin{array}{c}\text { BB\&T Corporation } \\
\text { (WINSTON SALEM, NC, } \\
\text { USA) }\end{array}$ & $\begin{array}{c}\text { BBVA Compass Bancshares } \\
\text { Inc. (BIRMINGHAM, AL, } \\
\text { USA) }\end{array}$ & $\begin{array}{l}\text { BMO Financial Corp. } \\
\text { (WILMINGTON, DE, } \\
\text { USA) }\end{array}$ \\
\hline $\begin{array}{c}\text { Citizens Financial Group } \\
\text { Inc. (NEWHAVEN, MO, } \\
\text { USA) }\end{array}$ & $\begin{array}{l}\text { Comerica Incorporated } \\
\text { (DALLAS, TX, USA) }\end{array}$ & $\begin{array}{c}\text { Deutsche Bank Trust } \\
\text { Corporation (NYC, NY, } \\
\text { USA) }\end{array}$ & $\begin{array}{c}\text { Discover Financial } \\
\text { Services (RIVERWOODS } \\
\text { IL, USA) }\end{array}$ \\
\hline $\begin{array}{c}\text { Fifth Third Bancorp } \\
\text { (CINCINNATI, OH, } \\
\text { USA) }\end{array}$ & $\begin{array}{c}\text { Huntington Bancshares } \\
\text { Incorporated (COLUMBUS, } \\
\text { OH, USA) }\end{array}$ & $\begin{array}{c}\text { KeyCorp (ALBANY, NY, } \\
\text { USA) }\end{array}$ & $\begin{array}{c}\text { M\&T Bank Corporation } \\
\text { (BUFFALO, NY, USA) }\end{array}$ \\
\hline $\begin{array}{l}\text { MUFG Americas } \\
\text { Holdings Corporation } \\
\text { (NYC, NY, USA) }\end{array}$ & $\begin{array}{c}\text { Regions Financial } \\
\text { Corporation } \\
\text { (BIRMINGHAM, AL, USA) }\end{array}$ & $\begin{array}{l}\text { Santander Holdings USA } \\
\text { Inc. (BOSTON, MA, USA) }\end{array}$ & $\begin{array}{l}\text { SunTrust Banks Inc. } \\
\text { (ATLANTA, GA, USA) }\end{array}$ \\
\hline \multicolumn{4}{|l|}{$\begin{array}{c}\text { Zions Bancorporation } \\
\text { (SALT LAKE CITY, UT, } \\
\text { USA) }\end{array}$} \\
\hline \multicolumn{4}{|c|}{ Minimum capital ratios in CCAR $2015(\%)$} \\
\hline & $\begin{array}{c}\text { 2014:Q4 } \\
\text { advanced-approaches BHCs }\end{array}$ & 2014:Q4 other BHCs & 2015-2016 all BHCs \\
\hline Tier 1 common ratio & 5 & 5 & 5 \\
\hline $\begin{array}{c}\text { Common equity Tier } 1 \\
\text { ratio }\end{array}$ & 4 & not applicable & 4.5 \\
\hline $\begin{array}{l}\text { Tier } 1 \text { risk-based capital } \\
\text { ratio }\end{array}$ & 5.5 & 4 & 6 \\
\hline $\begin{array}{c}\text { Total risk-based capital } \\
\text { ratio }\end{array}$ & 8 & 8 & 8 \\
\hline Tier 1 leverage ratio & 4 & 3 or 4 & 4 \\
\hline
\end{tabular}

DFAST - a complementary exercise to CCAR - is a forward-looking quantitative evaluation of the effect of stressful economic and financial market conditions on a bank's capital. In 2012, the Federal Reserve finalized the rules that implement the stress test requirements under the Dodd-Frank Act. ${ }^{23}$ All BHCs and IDIs with $\$ 10$ billion or more in total consolidated assets are required to conduct an annual company-run stress test. ${ }^{24}$ BHCs with assets greater than $\$ 50$ billion must conduct semiannual company-run stress tests and they also are subject to stress tests conducted by the Federal Reserve.

23 See Federal Reserve System, Federal Register 2012e.

24 As of June 30, 2016, there were 112 IDIs (1.9 percent of all IDIs) with $\$ 10$ billion or more in assets and they accounted for $\$ 13,540$ billion in assets (81.9 percent of the assets of all IDIs) (see FDIC Quarterly Banking Profile, Second Quarter 2016). 
The company-run tests must include three scenarios, and the institutions must publish a summary of the results. The estimated losses resulting from these tests are then subtracted from a bank's capital to determine the financial buffer that a bank has to insulate itself from shocks and losses. A bank effectively fails the tests if its capital falls below a required minimum level after the theoretical losses.

While DFAST is complementary to CCAR, both efforts are distinct testing exercises that rely on similar processes, data, supervisory exercises, and requirements. However, there are important differences between the two exercises. For CCAR, the Federal Reserve uses BHCs' planned capital actions and assesses whether a BHC would be capable of meeting supervisory expectations for minimum capital levels, even if stressful conditions emerged and the BHC did not reduce planned capital distributions. By contrast, for DFAST, the Federal Reserve uses a standardized set of assumptions that are specified in the Dodd-Frank Act stress test rules. DFAST is therefore far less detailed and less tailored to a specific BHC.

The requirements, expectations, and activities relating to DFAST and CCAR do not apply to any banking organizations with assets of $\$ 10$ billion or less. In particular, community banks are not required or expected to conduct the enterprise-wide stress tests that are required of larger organizations under the capital plan rule, the rules implementing the Dodd-Frank Act stress testing requirements, or the procedures described in the stress testing guidance for organizations with more than $\$ 10$ billion in total consolidated assets. As noted, BHCs with $\$ 10$ to $\$ 50$ billion in assets are only subject to firm-run stress tests for DFAST.

Stress testing requirements are a risk-assessment supervisory tool. The goal of stress tests conducted under the Dodd-Frank Act is to provide forward-looking information to supervisors to assist in their overall assessments of a bank's capital adequacy and to aid in identifying downside risks and the potential impact of adverse outcomes on the covered bank. Further, these stress tests support ongoing improvement in a bank's internal assessments of capital adequacy and overall capital planning. Yet, according to the Office of Inspector General of the Federal Reserve, "the Federal Reverse's Model Validation Unit does not currently conduct a formal assessment of the expertise required to validate each model or maintain an inventory to track the skills and expertise of reviewers". ${ }^{25}$ Furthermore, as evidence of additional problems at the Federal Reserve, "[T]he governance review findings include... a shortcoming in policies and procedures, insufficient model testing, insufficient planning and procedures to address the risks posed by potential key-personnel departures, and incomplete structures and information flows to ensure proper oversight of model risk management". These and other types of problems, such as a lack of transparency and forced homogeneity, call the usefulness of DFAST into question. ${ }^{26}$

On the positive side, CCAR and DFAST may induce banks to have more capital than they would if they were subject only to the traditional capital requirements. As a result of the stress tests and other post-crisis measures, banks may have become less susceptible to financial distress, but at the same time, to the extent that such measures have associated compliance costs, they may have affected lending decisions, especially to smaller firms (see Chen et al. (2017)).

\section{Not All Capital Ratios Are Equally Informative: Actual Capital Ratios Compared to Required Minimum Capital Ratios}

A number of recent academic studies suggest that a simple equity to asset leverage ratio equal to roughly 15 percent would have benefits that are associated with reducing the effects of financial stability that equal or exceed costs associated with implementing the regulation (see Karmakar (2016); Begenau and Landvoigt (2017); Egan et al. (2017); Barth and Miller (2018)). On the other hand,

At the same time, there were 97 BHCs (2.3 percent of all BHCs) with $\$ 10$ billion or more in assets and they accounted for $\$ 15,386$ billion in assets (93 percent of the assets of all BHCs).

25 See Office of the Inspector General 2015, pp. 9, 11.

26 Herring $(2016,2018)$ observes that eliminating DFAST alone would simplify capital requirements for US GSIBs. 
nearly all the capital adequacy guidelines set by BCBS are based on a bank's risk-weighted assets. In this section, we provide evidence that the various capital ratios imposed on banks are not equally informative about whether a bank is adequately capitalized.

The analysis proceeds by comparing the actual capital ratios to the required minimum capital ratios for some of the largest banks in the United States for every year over the period 2000-2017Q3. There are four such capital ratio comparisons: (1) the actual risk-based Tier 1 capital ratio is compared to the required minimum ratio of 4 percent from 2000 to 2012, 4.5 percent in 2013, 5.5 percent in 2014, and 6 percent in 2015 to 2017; (2) the actual risk-based total capital ratio is compared to the required minimum ratio of 8 percent; (3) the actual non-risk-based leverage ratio is compared to the minimum required ratio of 4 percent; and, (4) the actual non-risk-based tangible common equity ratio is compared to a (hypothetical) required minimum tangible common equity ratio of 4 percent. We also provide two other ratios that furnish an additional perspective on the four ratios just mentioned. These are the ratio of RWAs to total assets and the ratio of market capitalization to tangible common equity. The lower the former ratio, the less risk-based capital required, and in the latter case, a ratio greater than 1 indicates the market values a bank more than the book values indicate. Information is also provided about the averages and standard deviations for the different variables included in each of the tables as well as information about the number of banks with capital deficiencies or market-to-book values less than 1 .

The calculations are made for six of the eight GSIBs and twelve other large banks with total assets greater than $\$ 50$ billion, with the banks in every Appendix table ranked by asset size. Table A1 in the Appendix A shows the percentage by which the actual risk-weighted Tier 1 capital ratio exceeds the required minimum Tier 1 capital ratios for the eighteen banks from 2000 to the third quarter of 2017. All of the percentages are positive, which means that all the banks had capital buffers, or actual capital ratios, that exceeded the required minimum ratios. It is noteworthy that every bank's minimum capital buffer occurs in 2007 or earlier, while the maximum ratio occurs in 2009 or later. For nine of the eighteen banks, the minimum capital buffer occurs in 2007, which was in the midst of the banking crisis and the year before the bailout of the largest banks. Small banks were also bailed out, mainly in 2009. On the eve of the bailout, these banks more than satisfied their required minimum capital ratios. By 2015, moreover, all of the banks had more than met the new and higher capital requirement of 8.5 percent-6 percent plus the capital conservation buffer of 2.5 percent-applicable beginning in 2019 .

The situation is quite similar for the risk-weighted total capital ratio, as shown in Table A2 in the Appendix A. For every bank, the actual ratio exceeds the required minimum ratio, and by more than a trivial percentage, in each year. Importantly, just as in the case of Tier 1 capital, every bank had a positive capital buffer during 2007-2008, even though the United States was suffering the worst financial crisis since the Great Depression and it was in the midst of a severe recession. By 2015, moreover, all of the banks had sufficient capital to satisfy the minimum total capital ratio plus the capital conservation buffer of 10.5 percent.

To better understand how these banks' capital positions were changing over time, it is useful to look at the ratio of RWAs to total assets. Table A3 in the Appendix A presents this ratio in percentage terms for the eighteen banks for the years 2000-2017. Risk weighting makes it easier to exceed minimum capital ratios by lowering the total assets against which capital requirements are applied. The vast majority of the percentages in Table A3 are less than 100 percent because of the type of assets the banks have chosen to hold. After the risk-weighting formula is applied, almost all the banks' asset totals are less than the actual amount of assets. For example, for Citigroup, the ratio was 72 percent in 2000, and then trended downwards to a low of 51 percent in both 2008 and 2010. In the following two years, the ratio barely increased to 52 percent before increasing thereafter. In the two years when the ratio of risk-weighted assets to total assets was 51 percent, Citigroup did not need to have capital to back 49 percent of its assets. The decline in RWAs relative to total assets enabled the Tier 1 and total capital ratios to be higher with the same amount of capital then otherwise.

Table A4 in the Appendix A shows the actual non-risk-based leverage ratio minus the required minimum leverage ratio. All the capital buffers are positive. However, in contrast to Tables A1 and A2, 
the percentages for most of the banks' capital buffers are smaller. In particular, the three largest banks had the smallest capital buffers in any year over the entire period, with the exception of BNY Mellon, State Street, and BB\&T. In 2007, the figures were 2.00 percent for JPMorgan Chase, 1.04 percent for Bank of America, and 0.03 percent for Citigroup.

Another non-risk-based capital ratio is the tangible common equity ratio. Table A5 in the Appendix A shows the actual tangible common equity ratio minus a (hypothetical) required minimum tangible common equity ratio of 4 percent. This particular ratio, in which the numerator is based on the actual owner-contributed common equity less the actual intangible assets of a bank, is tangible common equity divided by tangible assets. The benefits of this measure lie in the fact that (1) it is less susceptible to guesswork or questionable manipulation, (2) market participants paid more attention to it than to other measures during the recent banking crisis, and (3) it is highly correlated to a market-value measure of capital. Regarding the latter point, based on the data for the banks in the Appendix tables, the correlation coefficient between tangible common equity capital and the market value of capital is 0.84 and it is highly statistically significant. Unlike Tables A1-A4, Table A5 contains quite a few negative percentages, as denoted by the cells with numerical values in parentheses. Moreover, in 2008, if tangible common equity had been the required capital measure for the minimum leverage ratio, nine banks would not have had enough capital to meet this minimum ratio. ${ }^{27}$ In 2007, one year before the bank bailout, neither Bank of America nor Citigroup would have met such a ratio. All of these banks received capital injections from the federal government. Importantly, according to Demirguc-Kunt et al. (2013), it is found that "the relationship between stock returns and capital is stronger when capital is measured by the leverage ratio rather than the risk-adjusted capital ratio ... [and] higher quality forms of capital, such as ... tangible common equity, [was] more relevant". In addition, Haldane (2012) points out that in terms of "pre-crisis predictive power ... [m] easures of risk-weighted capital are statistically insignificant, while the leverage ratio is significant at the $1 \%$ level". He adds that "[u]sing different methods and samples, other studies support the predictive superiority, or at least equivalence, of leverage over capital ratios (International Monetary Fund (2009); Demirguc-Kunt et al. (2013); Estrella et al. (2000))".

Table A6 in the Appendix A presents the market capitalization to actual tangible common equity ratios for the eighteen banks. ${ }^{28} \mathrm{~A}$ ratio greater than 1 means the market value of a bank is greater than indicated by its book value. The table shows that every bank had a ratio greater than 1 in every year from 2000 to 2006. In 2008 and 2009, during the midst of the banking crisis, nine banks had ratios less than 1 . The three largest banks had ratios less than 1 in 2008, while two of these banks also have ratios less than 1 in 2009. In the latter year, JPMorgan had a ratio of 1.04. During the period 2009 to 2017, only six banks had ratios that were greater than 1 every year, and those same banks also had ratios greater than 1 throughout the entire period from 2000 to 2017. Moreover, three of the banks-Bank of America, Citigroup, and Regions-had ratios less than 1 every year from 2008 to 2015.

As noted earlier, the data regarding capital ratios clearly indicate that whether banks have too little or excess capital depends on the specific capital ratio on which one focuses and whether the capital ratio is risk-based or not. Some of the ratios may indicate that a bank has sufficient capital to

27 It should be noted that BNY Mellon would not have had enough capital to meet this minimum ratio from 2007 to 2017 Q3. However, BNY Mellon is a large custodial bank that provides investment management, investment services and wealth management that help institutions and individuals succeed in markets all over the world. Given its business model that is quite unique, this lack of capital posed no significant risk. Indeed, in February 2009, it was one of only three of the nation's 19 largest banks that when stress-tested would be profitable in 2010 (see http:/ / archive.fortune.com/2009/07/23/ news/companies/tarp_banks_new_york_mellon.fortune/index.htm). In 2013, stress tests indicated it was the bank least affected by hypothetical extreme economic scenarios among banks tested (see https:/ / www.americanbanker.com/news / fed-unveils-dodd-frank-stress-test-results).

28 A referee points out that the advantage of market based indicators is that they may incorporate risk increase faster and on a continuous basis respect to accounting based measures that can only be updated quarterly and with a significant time lapse. It is added, however, that market based ratios tend to also reflect all the noise and irrational recurrent market dynamics (plus they are available only for listed banks with a liquid market). 
satisfy regulatory requirements, whereas other ratios may indicate that there is a deficiency in capital. This means that a higher regulatory capital ratio being imposed on banks may or may not affect bank behavior. To determine the outcome, one must know the specific ratio that regulators choose to increase. Importantly, in the aggregate, the market reveals that all ratios are not equally revealing about a bank's actual capital adequacy, as market participants pay more attention to some ratios than others when assessing whether a bank is adequately capitalized. Indeed, according to Graeme Wearden of The Guardian, the tangible common equity ratio ... takes a more conservative view than other measures, such as Tier 1 capital ratios, and has become an increasingly important way of assessing the banking sector as the financial crisis ... [in 2007-2008] deepened. ${ }^{29}$ Elliott $(2010)^{30}$, moreover, states that "[c]ommon stock investors, who have the lowest repayment priority, have focused intensely at times during the recent financial crisis on the most conservative measure, tangible common equity". He adds that " ... investors recognize that they [intangible assets] are particularly difficult to turn into cash in a crisis and that they can lose value if a bank's overall franchise deteriorates. For this reason, many investors prefer to treat them as worthless when evaluating capital adequacy. Such investors focus on tangible common equity". ${ }^{31}$

\section{Concluding Comments}

Bank regulatory standards have been a work in progress in countries around the world. They have changed several times in recent decades, and most significantly in response to the last banking crisis. They have become ever more stringent and complex for banks of all sizes, but especially for the largest banks. This is certainly the case in the United States. In addition to the legally mandated actions that banking regulators are required to take as a bank's capital declines below specified minimum levels, regulators now subject the larger banks to new comprehensive capital analyses and supervisory stress. Yet, it is not clear whether regulators took appropriate actions in a timely manner to lessen the severity of the most recent banking crisis, nor whether the more extensive analyses and testing contribute to a safer and sounder banking system.

What is clear is that understanding what counts as capital and how capital requirements vary for banks of different asset sizes and business models has become mind-boggling, to say the least. Most importantly, our comparison of various actual capital ratios to the required minimum ratios for a select and important group of banks is quite revealing. The differences found demonstrate the lack of any clear message about whether a bank is or is not adequately capitalized. ${ }^{32}$

Whether banks have too little capital or excess capital depends on the specific required capital ratio on which one focuses and whether the required capital ratio is risk-based or non-risk-based. Some ratios indicate a bank has sufficient capital; other ratios indicate the opposite. Of course, bank supervisors may prefer a regulatory regime with several binding capital ratios, including risk-weighted and unweighted ratios, based on their view that there is no unique ratio that can always help guard against effective risk.

Nonetheless, this situation contributes to confusion, and simply adding more capital requirements is not the way to promote a safer and sounder banking system. Indeed, in 2000, only three different regulatory capital requirements were imposed on banks, two of which were risk-based. However, today there are seven such requirements, six of which are risk-based. These include Tier 1 capital ratio, total capital ratio, leverage ratio (non risk-based), CET1 capital ratio, capital conservation buffer, countercyclical capital buffer, and capital surcharge for GSIBs. While beyond the scope of this review,

29 See https://www.theguardian.com/business/2009/feb/24/businessglossary-banking.

30 In 2016 Douglas Elliott was the lead author of a 150-page study analyzing the impacts of the Basel reforms, building on a similar paper from several years earlier for the IMF.

31 Also, Haldane (2012) states that "[m]ore than half of all investors do not understand or trust banks' risk weights ... ". He adds that "Their multiplicity and complexity have undermined transparency and, with it, market discipline".

32 As a referee pointed out, the lack of any clear message may be better appreciated by comparing the evolution of a bank's capital ratio with its ratings. Given the current length of this paper, this exercise is left for another time. 
instead of the existing complexity in the regulatory capital requirements, it may be better to focus to a far greater degree on a simpler, tangible equity leverage ratio as an appropriate capital requirement. ${ }^{33}$ This ratio is fairly straightforward and easily understood by market participants. In contrast, too much of a focus on the currently constructed risk-based capital ratios has all too often been misleading with respect to whether banks were adequately capitalized. More generally, financial stability depends on not just an appropriate capital ratio, but other regulatory and supervisory factors that are well beyond the scope of this review.

Author Contributions: J.B. and S.M. contributed equally to the conception of the paper. J.B. did much of the Basel and non-US Basel investigation, while S.M. did all of the US Federal Register and CFR-related investigation, including the empirical work. J.B. did much of the original draft preparation and editing, while S.M. did much of the subsequent draft preparation, review and editing.

Funding: This research received no external funding.

Conflicts of Interest: The authors declare no conflict of interest. The opinions expressed in this paper are their individual one and does not represent the organizations/ academic institutions they are engaged with.

33 For a discussion of the appropriate level of the regulatory capital ratio that takes into account the risk of a systemic banking crisis, see for example Karmakar (2016), Begenau and Landvoigt (2017), Egan et al. (2017), Barth and Miller (2018) and references therein. It should also be noted that a referee indicated that in the supervisory risk assessment process a bank's specific risk factors could and should be taken into account so that the capital requirement could be set and measured in terms of a simple indicator such as the leverage ratio. 


\section{Appendix A. Data Tables}

Table A1. Actual Tier 1 Capital Ratio Minus Required Minimum Tier 1 Capital Ratios.

\begin{tabular}{|c|c|c|c|c|c|c|c|c|c|c|c|c|c|c|c|c|c|c|}
\hline & 2000 & 2001 & 2002 & 2003 & 2004 & 2005 & 2006 & 2007 & 2008 & 2009 & 2010 & 2011 & 2012 & 2013 & 2014 & 2015 & 2016 & $2017 Q 3$ \\
\hline Minimum requirement & 4.00 & 4.00 & 4.00 & 4.00 & 4.00 & 4.00 & 4.00 & 4.00 & 4.00 & 4.00 & 4.00 & 4.00 & 4.00 & 4.50 & 5.50 & 6.00 & 6.00 & 6.00 \\
\hline JPMorgan & 4.50 & 4.29 & 4.24 & 4.50 & 4.70 & 4.50 & 4.70 & 4.40 & 6.90 & 7.10 & 8.10 & 8.30 & 8.60 & 7.40 & 6.10 & 7.70 & 8.20 & 8.30 \\
\hline Bank of America & 3.50 & 4.30 & 4.22 & 3.85 & 4.20 & 4.25 & 4.64 & 2.87 & 5.15 & 6.40 & 7.24 & 8.40 & 8.89 & 7.94 & 7.60 & 6.90 & 7.60 & 8.00 \\
\hline Citigroup & 4.38 & 4.42 & 4.47 & 4.91 & 4.74 & 4.79 & 4.59 & 3.12 & 7.92 & 7.67 & 8.91 & 9.55 & 10.06 & 9.20 & 7.60 & 9.49 & 9.84 & 9.30 \\
\hline Wells Fargo & 3.29 & 2.99 & 3.60 & 4.42 & 4.41 & 4.26 & 4.95 & 3.59 & 3.84 & 5.25 & 7.16 & 7.33 & 7.75 & 7.83 & 6.95 & 7.03 & 6.82 & 7.95 \\
\hline U.S. Bancorp & 3.20 & 3.70 & 4.00 & 5.20 & 4.60 & 4.20 & 4.80 & 4.30 & 6.60 & 5.60 & 6.50 & 6.80 & 6.80 & 6.70 & 5.80 & 5.10 & 5.00 & 5.10 \\
\hline BNY Mellon & 4.60 & 4.11 & 3.58 & 3.44 & 4.31 & 4.38 & 4.19 & 5.32 & 9.30 & 8.10 & 9.40 & 11.00 & 11.10 & 11.70 & 6.70 & 6.30 & 6.60 & 8.60 \\
\hline PNC & 4.60 & 3.80 & 4.80 & 5.50 & 5.00 & 4.30 & 6.40 & 2.80 & 5.70 & 7.40 & 8.10 & 8.60 & 7.60 & 7.90 & 7.10 & 6.00 & 6.00 & 5.60 \\
\hline State Street & 10.50 & 9.60 & 13.10 & 10.00 & 9.30 & 7.70 & 9.70 & 7.20 & 16.30 & 13.70 & 16.50 & 14.80 & 15.10 & 12.80 & 9.20 & 9.90 & 8.70 & 8.50 \\
\hline BB\&T & 5.70 & 5.80 & 5.20 & 5.33 & 5.20 & 5.30 & 5.00 & 5.10 & 8.30 & 7.50 & 7.80 & 8.50 & 6.50 & 7.30 & 6.90 & 5.80 & 6.00 & 5.80 \\
\hline SunTrust & 3.09 & 4.02 & 3.47 & 3.85 & 3.16 & 3.01 & 3.72 & 2.93 & 6.87 & 8.96 & 9.67 & 6.90 & 7.13 & 6.31 & 5.30 & 4.80 & 4.28 & 4.74 \\
\hline Fifth Third & 9.02 & 8.36 & 7.70 & 6.94 & 6.31 & 4.38 & 4.39 & 4.50 & 6.59 & 9.31 & 9.94 & 7.91 & 6.65 & 5.86 & 5.33 & 4.93 & 5.50 & 5.72 \\
\hline Regions & 5.14 & 5.66 & 4.98 & 5.72 & 5.04 & 4.60 & 4.00 & 3.29 & 6.38 & 7.54 & 8.40 & 9.28 & 8.00 & 7.10 & 7.04 & 5.70 & 5.90 & 6.10 \\
\hline Northern Trust & 5.79 & 6.88 & 7.13 & 7.10 & 7.00 & 5.70 & 5.80 & 5.70 & 9.10 & 9.40 & 9.60 & 8.50 & 8.80 & 8.90 & 7.70 & 6.50 & 7.70 & 8.60 \\
\hline $\mathrm{M} \& \mathrm{~T}$ & 3.49 & 3.37 & 4.02 & 3.30 & 3.31 & 3.56 & 3.74 & 2.84 & 4.83 & 4.59 & 5.47 & 5.67 & 6.22 & 7.50 & 6.97 & 6.68 & 5.92 & 6.25 \\
\hline KeyCorp & 3.72 & 3.43 & 3.74 & 4.35 & 3.22 & 3.59 & 4.24 & 3.44 & 6.92 & 8.75 & 11.16 & 8.99 & 8.15 & 7.46 & 6.40 & 5.36 & 4.89 & 5.11 \\
\hline Comerica & 3.52 & 3.98 & 4.08 & 4.72 & 4.77 & 4.46 & 4.02 & 3.51 & 6.66 & 8.46 & 6.13 & 6.37 & 6.14 & 6.14 & 5.00 & 4.54 & 3.89 & 5.51 \\
\hline Huntington & 3.19 & 3.24 & 4.69 & 4.53 & 5.08 & 5.13 & 4.93 & 3.51 & 6.72 & 8.03 & 7.55 & 8.11 & 8.01 & 7.78 & 6.00 & 4.53 & 4.90 & 5.30 \\
\hline Zions & 4.53 & 4.25 & 5.26 & 5.42 & 5.35 & 3.52 & 3.98 & 3.57 & 6.22 & 6.53 & 10.78 & 12.13 & 9.38 & 8.27 & 8.97 & 8.08 & 7.49 & 7.33 \\
\hline Average ratio & 4.76 & 4.79 & 5.13 & 5.17 & 4.98 & 4.54 & 4.88 & 4.00 & 7.24 & 7.79 & 8.80 & 8.73 & 8.38 & 8.01 & 6.81 & 6.41 & 6.40 & 6.77 \\
\hline Standard deviation & 2.02 & 1.82 & 2.30 & 1.59 & 1.45 & 1.03 & 1.39 & 1.19 & 2.65 & 2.01 & 2.48 & 2.17 & 2.15 & 1.78 & 1.16 & 1.58 & 1.61 & 1.52 \\
\hline Number of banks with capital shortfall & 0 & 0 & 0 & 0 & 0 & 0 & 0 & 0 & 0 & 0 & 0 & 0 & 0 & 0 & 0 & 0 & 0 & 0 \\
\hline Number of banks reporting excess capital & 18 & 18 & 18 & 18 & 18 & 18 & 18 & 18 & 18 & 18 & 18 & 18 & 18 & 18 & 18 & 18 & 18 & 18 \\
\hline
\end{tabular}

Note: The required minimum Tier 1 capital ratio was 4 percent from 2000 to 2012, 4.5 percent in 2013, 5.5 percent in 2014, and 6 percent in 2015,2016 and 2017. 
Table A2. Actual Total Capital Ratio Minus Required Minimum Total Capital Ratio of 8 Percent.

\begin{tabular}{|c|c|c|c|c|c|c|c|c|c|c|c|c|c|c|c|c|c|c|}
\hline & 2000 & 2001 & 2002 & 2003 & 2004 & 2005 & 2006 & 2007 & 2008 & 2009 & 2010 & 2011 & 2012 & 2013 & 2014 & 2015 & 2016 & $2017 Q 3$ \\
\hline Minimum requirement & 8.00 & 8.00 & 8.00 & 8.00 & 8.00 & 8.00 & 8.00 & 8.00 & 8.00 & 8.00 & 8.00 & 8.00 & 8.00 & 8.00 & 8.00 & 8.00 & 8.00 & 8.00 \\
\hline JPMorgan & 4.00 & 3.88 & 3.95 & 3.80 & 4.20 & 4.00 & 4.30 & 4.60 & 6.80 & 6.80 & 7.50 & 7.40 & 7.30 & 6.30 & 5.10 & 8.00 & 8.40 & 8.40 \\
\hline Bank of America & 3.04 & 4.67 & 4.43 & 3.87 & 3.73 & 3.08 & 3.88 & 3.02 & 5.00 & 6.66 & 7.77 & 8.75 & 8.31 & 7.44 & 6.60 & 7.70 & 8.30 & 8.50 \\
\hline Citigroup & 3.23 & 2.92 & 3.25 & 4.04 & 3.85 & 4.02 & 3.65 & 2.70 & 7.70 & 7.25 & 8.59 & 8.99 & 9.26 & 8.68 & 6.53 & 10.54 & 11.08 & 10.54 \\
\hline Wells Fargo & 2.43 & 2.45 & 3.31 & 4.21 & 4.07 & 3.64 & 4.50 & 2.68 & 3.83 & 5.26 & 7.01 & 6.76 & 6.63 & 7.43 & 7.53 & 7.45 & 8.08 & 9.28 \\
\hline U.S. Bancorp & 2.60 & 3.70 & 4.40 & 5.60 & 5.10 & 4.50 & 4.60 & 4.20 & 6.30 & 4.90 & 5.30 & 5.30 & 5.10 & 5.20 & 5.60 & 5.10 & 5.20 & 5.20 \\
\hline BNY Mellon & 4.92 & 3.57 & 3.96 & 3.49 & 4.21 & 4.48 & 4.49 & 5.25 & 9.10 & 8.00 & 8.30 & 9.00 & 8.40 & 9.00 & 4.50 & 4.50 & 5.00 & 7.60 \\
\hline PNC & 4.57 & 3.80 & 4.50 & 5.80 & 5.00 & 4.10 & 5.50 & 2.30 & 5.20 & 7.00 & 7.60 & 7.80 & 6.70 & 7.80 & 7.90 & 6.70 & 6.30 & 5.70 \\
\hline State Street & 7.60 & 6.50 & 10.00 & 7.80 & 6.70 & 6.00 & 7.90 & 4.70 & 13.60 & 11.10 & 14.00 & 12.50 & 12.60 & 11.70 & 8.60 & 9.40 & 8.00 & 7.60 \\
\hline $\mathrm{BB} \& \mathrm{~T}$ & 4.20 & 5.30 & 5.40 & 4.43 & 6.50 & 6.40 & 6.30 & 6.20 & 9.40 & 7.80 & 7.50 & 7.70 & 5.40 & 6.30 & 6.90 & 6.30 & 6.10 & 5.90 \\
\hline SunTrust & 2.85 & 4.18 & 3.62 & 3.75 & 2.36 & 2.57 & 3.11 & 2.30 & 6.04 & 8.43 & 8.54 & 5.67 & 5.48 & 4.81 & 4.51 & 4.54 & 4.26 & 4.69 \\
\hline Fifth Third & 6.76 & 6.42 & 5.51 & 5.38 & 4.31 & 2.45 & 3.07 & 2.16 & 6.78 & 9.48 & 10.14 & 8.09 & 6.42 & 6.08 & 6.33 & 6.13 & 7.02 & 7.16 \\
\hline Regions & 3.40 & 5.23 & 5.84 & 6.46 & 5.51 & 4.76 & 3.54 & 3.25 & 6.64 & 7.78 & 8.35 & 8.99 & 7.38 & 6.70 & 7.26 & 5.90 & 6.10 & 6.20 \\
\hline Northern Trust & 4.85 & 6.25 & 6.13 & 6.00 & 5.30 & 4.30 & 3.90 & 3.90 & 7.40 & 7.80 & 7.60 & 6.20 & 6.30 & 7.80 & 7.00 & 6.20 & 7.10 & 8.40 \\
\hline M\&T & 3.19 & 2.72 & 3.20 & 3.20 & 2.91 & 2.85 & 3.78 & 3.18 & 4.83 & 4.30 & 5.08 & 5.26 & 5.39 & 7.07 & 7.21 & 6.92 & 6.09 & 6.87 \\
\hline KeyCorp & 3.48 & 3.41 & 4.11 & 4.57 & 3.47 & 3.47 & 4.43 & 3.38 & 6.82 & 8.95 & 11.12 & 8.51 & 7.13 & 6.33 & 5.89 & 4.97 & 4.85 & 5.09 \\
\hline Comerica & 3.58 & 3.70 & 3.76 & 4.71 & 4.75 & 3.75 & 3.63 & 3.20 & 6.72 & 8.93 & 6.54 & 6.25 & 2.10 & 5.05 & 4.54 & 4.69 & 5.27 & 5.65 \\
\hline Huntington & 2.46 & 2.29 & 3.60 & 3.95 & 4.48 & 4.42 & 4.79 & 2.85 & 5.91 & 6.41 & 6.46 & 6.77 & 6.51 & 6.57 & 5.56 & 4.64 & 5.05 & 5.39 \\
\hline Zions & 2.83 & 4.20 & 4.94 & 5.52 & 6.05 & 4.23 & 4.29 & 3.68 & 6.32 & 5.28 & 9.15 & 10.06 & 2.96 & 6.67 & 8.27 & 8.12 & 7.24 & 6.99 \\
\hline Average ratio & 3.89 & 4.18 & 4.66 & 4.81 & 4.58 & 4.06 & 4.43 & 3.53 & 6.91 & 7.34 & 8.14 & 7.78 & 6.63 & 7.05 & 6.44 & 6.54 & 6.64 & 6.95 \\
\hline Standard deviation & 1.43 & 1.31 & 1.61 & 1.21 & 1.16 & 1.03 & 1.18 & 1.10 & 2.16 & 1.74 & 2.09 & 1.84 & 2.31 & 1.63 & 1.28 & 1.74 & 1.70 & 1.62 \\
\hline Number of banks with capital shortfall & 0 & 0 & 0 & 0 & 0 & 0 & 0 & 0 & 0 & 0 & 0 & 0 & 0 & 0 & 0 & 0 & 0 & 0 \\
\hline Number of banks reporting excess capital & 18 & 18 & 18 & 18 & 18 & 18 & 18 & 18 & 18 & 18 & 18 & 18 & 18 & 18 & 18 & 18 & 18 & 18 \\
\hline
\end{tabular}


Table A3. Risk-Weighted Assets as a Percentage of Total Assets.

\begin{tabular}{|c|c|c|c|c|c|c|c|c|c|c|c|c|c|c|c|c|c|c|}
\hline & 2000 & 2001 & 2002 & 2003 & 2004 & 2005 & 2006 & 2007 & 2008 & 2009 & 2010 & 2011 & 2012 & 2013 & 2014 & 2015 & 2016 & $2017 Q^{3}$ \\
\hline JPMorgan & 62 & 66 & 60 & 66 & 68 & 71 & 69 & 67 & 57 & 59 & 55 & 54 & 54 & 58 & 63 & 62 & 59 & 58 \\
\hline Bank of America & 84 & 81 & 79 & 78 & 71 & 70 & 72 & 71 & 73 & 69 & 64 & 60 & 55 & 62 & 60 & 65 & 54 & 62 \\
\hline Citigroup & 72 & 66 & 63 & 59 & 57 & 59 & 56 & 57 & 51 & 59 & 51 & 52 & 52 & 58 & 70 & 66 & 63 & 61 \\
\hline Wells Fargo & 81 & 85 & 81 & 79 & 81 & 80 & 85 & 84 & 84 & 82 & 78 & 77 & 76 & 75 & 74 & 72 & 69 & 66 \\
\hline U.S. Bancorp & 97 & 95 & 90 & 84 & 87 & 88 & 89 & 89 & 87 & 84 & 80 & 80 & 81 & 82 & 79 & 81 & 80 & 79 \\
\hline BNY Mellon & - & 36 & 34 & 30 & 78 & 78 & 75 & 61 & 49 & 50 & 41 & 31 & 31 & 30 & 44 & 41 & 44 & 43 \\
\hline PNC & 89 & 85 & 87 & 84 & 81 & 83 & 84 & 83 & 86 & 86 & 82 & 85 & 85 & 85 & 82 & 82 & 82 & 82 \\
\hline State Street & 36 & 40 & 32 & 39 & 42 & 48 & 44 & 45 & 40 & 43 & 37 & 33 & 32 & 33 & 39 & 41 & 41 & 46 \\
\hline BB\&T & 71 & 72 & 72 & 73 & 73 & 74 & 75 & 75 & 72 & 71 & 75 & 69 & 74 & 75 & 77 & 79 & 80 & 80 \\
\hline SunTrust & 93 & 96 & 92 & 91 & 86 & 88 & 89 & 92 & 86 & 80 & 77 & 75 & 78 & 85 & 85 & 86 & 86 & 85 \\
\hline Fifth Third & 80 & 84 & 81 & 82 & 88 & 93 & 102 & 104 & 94 & 89 & 90 & 90 & 90 & 89 & 85 & 86 & 84 & 83 \\
\hline Regions & 75 & 74 & 75 & 76 & 77 & 81 & 81 & 82 & 79 & 73 & 72 & 72 & 76 & 83 & 83 & 84 & 82 & 82 \\
\hline Northern Trust & 70 & 65 & 69 & 67 & 67 & 64 & 65 & 66 & 62 & 59 & 61 & 57 & 60 & 57 & 57 & 63 & 55 & - \\
\hline M\&T & 84 & 85 & 84 & 88 & 86 & 86 & 87 & 86 & 56 & 61 & 57 & 92 & 92 & 86 & 80 & 77 & 82 & - \\
\hline KeyCorp & 96 & 103 & 101 & 100 & 106 & 109 & 110 & 111 & 102 & 92 & 85 & 87 & 89 & 90 & 91 & 95 & 89 & 86 \\
\hline Comerica & 85 & 116 & 113 & 113 & 117 & 121 & 122 & 120 & 108 & 104 & 111 & 104 & 102 & 99 & 99 & 97 & 93 & 94 \\
\hline Huntington & 94 & 98 & 99 & 92 & 91 & 90 & 88 & 84 & 86 & 84 & 81 & 84 & 85 & 84 & 82 & 82 & 78 & 77 \\
\hline Zions & 73 & 79 & 80 & 84 & 87 & 88 & 92 & 90 & 94 & 100 & 84 & 81 & 79 & 81 & 80 & 78 & 79 & 78 \\
\hline Average ratio & 78.94 & 79.22 & 77.33 & 76.94 & 80.17 & 81.72 & 82.50 & 81.50 & 75.89 & 74.72 & 71.17 & 71.28 & 71.72 & 72.89 & 73.89 & 74.28 & 72.22 & 72.63 \\
\hline Standard deviation & 15.02 & 20.24 & 20.86 & 19.94 & 16.86 & 17.01 & 18.52 & 18.92 & 19.51 & 17.11 & 18.45 & 19.94 & 20.13 & 19.29 & 15.75 & 15.67 & 15.72 & 14.85 \\
\hline $\begin{array}{l}\text { Number of banks with risk-weigthed } \\
\text { assests more than total assets }\end{array}$ & 0 & 2 & 2 & 1 & 2 & 2 & 3 & 3 & 2 & 1 & 1 & 1 & 1 & 0 & 0 & 0 & 0 & 0 \\
\hline $\begin{array}{l}\text { Number of banks with risk-weigthed } \\
\text { assests less than total assets }\end{array}$ & 17 & 16 & 16 & 16 & 16 & 16 & 15 & 15 & 16 & 16 & 17 & 17 & 17 & 18 & 18 & 18 & 18 & 16 \\
\hline
\end{tabular}

Note: The ratios for Fifth Third, KeyCorp, and Comerica exceed 100 percent because of off-balance-sheet items. 
Table A4. Actual Leverage Ratio Minus Required Minimum Leverage Ratio of 4 Percent

\begin{tabular}{|c|c|c|c|c|c|c|c|c|c|c|c|c|c|c|c|c|c|c|}
\hline & 2000 & 2001 & 2002 & 2003 & 2004 & 2005 & 2006 & 2007 & 2008 & 2009 & 2010 & 2011 & 2012 & 2013 & 2014 & 2015 & 2016 & $2017 Q 3$ \\
\hline Minimum requirement & 4.00 & 4.00 & 4.00 & 4.00 & 4.00 & 4.00 & 4.00 & 4.00 & 4.00 & 4.00 & 4.00 & 4.00 & 4.00 & 4.00 & 4.00 & 4.00 & 4.00 & 4.00 \\
\hline JPMorgan & 1.40 & 1.17 & 1.06 & 1.60 & 2.20 & 2.30 & 2.20 & 2.00 & 2.90 & 2.90 & 3.00 & 2.80 & 3.10 & 3.10 & 3.60 & 4.50 & 4.40 & 4.40 \\
\hline Bank of America & 2.12 & 2.56 & 2.29 & 1.73 & 1.89 & 1.91 & 2.36 & 1.04 & 2.44 & 2.91 & 3.21 & 3.53 & 3.37 & 3.86 & 5.60 & 4.60 & 4.90 & 5.00 \\
\hline Citigroup & 1.97 & 1.64 & 1.49 & 1.56 & 1.20 & 1.35 & 1.16 & 0.03 & 2.08 & 2.89 & 2.60 & 3.19 & 3.48 & 4.20 & 5.03 & 6.18 & 6.09 & 5.64 \\
\hline Wells Fargo & 2.49 & 2.25 & 2.58 & 2.93 & 3.08 & 2.99 & 3.89 & 2.83 & 10.52 & 3.87 & 5.19 & 5.03 & 5.47 & 5.60 & 5.45 & 5.37 & 4.95 & 5.27 \\
\hline U.S. Bancorp & 3.70 & 3.70 & 3.70 & 4.00 & 3.90 & 3.60 & 4.20 & 3.90 & 5.80 & 4.50 & 5.10 & 5.10 & 5.20 & 5.60 & 5.30 & 5.30 & 5.00 & 5.10 \\
\hline BNY Mellon & 3.49 & 2.70 & 2.48 & 1.82 & 2.41 & 2.60 & 2.67 & 2.53 & 2.90 & 2.50 & 1.80 & 1.20 & 1.30 & 1.40 & 1.60 & 2.00 & 2.60 & 2.80 \\
\hline PNC & 4.03 & 2.80 & 4.10 & 4.20 & 3.60 & 3.20 & 5.30 & 2.20 & 13.50 & 6.10 & 6.20 & 7.10 & 6.40 & 7.10 & 6.80 & 6.10 & 5.80 & 5.90 \\
\hline State Street & 1.40 & 1.40 & 1.60 & 1.60 & 1.50 & 1.60 & 1.80 & 1.30 & 3.80 & 4.50 & 4.20 & 3.30 & 3.10 & 2.90 & 2.40 & 2.90 & 2.50 & 3.40 \\
\hline $\mathrm{BB} \& \mathrm{~T}$ & 3.30 & 3.20 & 2.90 & 3.15 & 3.10 & 3.20 & 3.20 & 3.20 & 5.90 & 4.50 & 5.10 & 5.00 & 4.20 & 5.30 & 5.90 & 5.80 & 6.00 & 5.90 \\
\hline SunTrust & 2.98 & 3.94 & 3.30 & 3.37 & 2.64 & 2.65 & 3.23 & 2.90 & 6.45 & 6.90 & 6.94 & 4.75 & 4.91 & 5.58 & 5.64 & 5.67 & 5.22 & 5.50 \\
\hline Fifth Third & 6.77 & 6.53 & 5.73 & 5.11 & 4.89 & 4.08 & 4.44 & 3.72 & 6.27 & 8.43 & 8.79 & 7.10 & 6.05 & 5.64 & 5.66 & 5.54 & 5.90 & 5.97 \\
\hline Regions & 2.90 & 3.41 & 2.92 & 3.49 & 3.47 & 3.42 & 4.30 & 2.66 & 4.47 & 4.90 & 5.30 & 5.91 & 5.65 & 6.10 & 6.86 & 6.40 & 6.10 & 6.20 \\
\hline Northern Trust & 2.91 & 3.93 & 3.76 & 3.60 & 3.60 & 3.10 & 2.70 & 2.80 & 4.50 & 4.80 & 4.80 & 3.30 & 4.20 & 3.90 & 3.80 & 3.50 & 4.00 & 4.00 \\
\hline M\&T & 2.66 & 2.55 & 3.05 & 2.98 & 2.73 & 2.94 & 3.20 & 2.59 & 4.35 & 4.43 & 5.33 & 5.28 & 6.07 & 6.78 & 6.17 & 6.89 & 5.99 & 6.35 \\
\hline KeyCorp & 3.71 & 3.65 & 4.16 & 4.55 & 3.96 & 4.53 & 4.98 & 4.39 & 7.05 & 7.72 & 9.02 & 7.79 & 7.41 & 7.11 & 7.26 & 6.71 & 5.90 & 5.83 \\
\hline Comerica & 4.90 & 5.36 & 5.30 & 6.13 & 6.37 & 5.99 & 5.76 & 5.26 & 7.77 & 9.25 & 7.26 & 6.92 & 6.52 & 6.82 & 6.44 & 6.22 & 6.18 & 6.87 \\
\hline Huntington & 2.93 & 3.41 & 4.89 & 3.98 & 4.42 & 4.34 & 4.00 & 2.77 & 5.82 & 6.09 & 5.41 & 6.28 & 6.47 & 6.67 & 5.74 & 4.79 & 4.70 & 4.96 \\
\hline Zions & 2.38 & 2.56 & 3.56 & 4.06 & 4.31 & 4.16 & 3.86 & 3.37 & 5.99 & 6.38 & 8.56 & 9.40 & 6.96 & 6.48 & 7.82 & 7.26 & 7.09 & 6.58 \\
\hline Average ratio & 3.11 & 3.15 & 3.27 & 3.33 & 3.29 & 3.22 & 3.51 & 2.75 & 5.70 & 5.20 & 5.43 & 5.17 & 4.99 & 5.23 & 5.39 & 5.32 & 5.18 & 5.32 \\
\hline Standard deviation & 1.28 & 1.32 & 1.28 & 1.31 & 1.28 & 1.14 & 1.24 & 1.22 & 2.86 & 1.98 & 2.09 & 2.06 & 1.65 & 1.65 & 1.63 & 1.40 & 1.22 & 1.09 \\
\hline Number of banks with capital shortfall & 0 & 0 & 0 & 0 & 0 & 0 & 0 & 0 & 0 & 0 & 0 & 0 & 0 & 0 & 0 & 0 & 0 & 0 \\
\hline Number of banks reporting excess capital & 18 & 18 & 18 & 18 & 18 & 18 & 18 & 18 & 18 & 18 & 18 & 18 & 18 & 18 & 18 & 18 & 18 & 18 \\
\hline
\end{tabular}


Table A5. Actual Tangible Common Equity Ratio Minus Assumed Required Minimum Tangible Common Equity Ratio of 4 Percent.

\begin{tabular}{|c|c|c|c|c|c|c|c|c|c|c|c|c|c|c|c|c|c|c|}
\hline & 2000 & 2001 & 2002 & 2003 & 2004 & 2005 & 2006 & 2007 & 2008 & 2009 & 2010 & 2011 & 2012 & 2013 & 2014 & 2015 & 2016 & 2017Q3 \\
\hline Minimum requirement & 4.00 & 4.00 & 4.00 & 4.00 & 4.00 & 4.00 & 4.00 & 4.00 & 4.00 & 4.00 & 4.00 & 4.00 & 4.00 & 4.00 & 4.00 & 4.00 & 4.00 & 4.00 \\
\hline JPMorgan & -0.43 & -0.35 & 0.22 & 0.59 & 1.09 & 0.82 & 0.87 & 0.76 & -0.17 & 1.27 & 1.59 & 1.62 & 2.26 & 2.35 & 2.46 & 3.23 & 3.23 & 3.52 \\
\hline Bank of America & 1.47 & 1.96 & 1.83 & 1.03 & 0.79 & 0.24 & 0.14 & -0.65 & -1.17 & 0.51 & 1.86 & 2.52 & 2.63 & 3.10 & 3.38 & 3.69 & 3.69 & 3.74 \\
\hline Citigroup & 1.52 & 0.98 & 0.70 & 0.53 & 0.51 & 0.68 & -0.21 & -1.28 & -2.44 & 2.49 & 2.89 & 3.90 & 4.46 & 5.05 & 5.47 & 6.06 & 6.06 & 6.50 \\
\hline Wells Fargo & 2.01 & 1.59 & 1.71 & 2.11 & 2.25 & 2.12 & 3.15 & 1.93 & -1.67 & 1.44 & 2.72 & 3.40 & 4.04 & 4.13 & 4.08 & 4.21 & 4.21 & 4.08 \\
\hline U.S. Bancorp & 2.18 & 1.52 & 1.71 & 2.12 & 2.45 & 2.29 & 1.17 & 0.74 & -0.81 & 1.10 & 1.22 & 2.00 & 2.54 & 2.72 & 2.67 & 2.84 & 2.84 & 2.84 \\
\hline BNY Mellon & 1.78 & 1.36 & - & 0.91 & 1.56 & 1.68 & 1.14 & -0.19 & -2.37 & -0.25 & -0.15 & -0.57 & -0.29 & -0.19 & -0.18 & -0.07 & -0.07 & -0.24 \\
\hline PNC & 1.75 & 1.13 & 2.59 & 2.30 & 1.68 & 1.05 & 3.34 & 0.61 & -1.26 & -0.47 & 3.43 & 4.53 & 4.34 & 4.77 & 4.88 & 5.40 & 5.40 & 5.10 \\
\hline State Street & 0.71 & 0.67 & 0.93 & 0.55 & 0.53 & 0.75 & 1.15 & -0.51 & -1.03 & 1.36 & 2.30 & 1.17 & 1.54 & 0.89 & 0.38 & 0.70 & 0.70 & 0.38 \\
\hline BB\&T & 3.07 & 3.53 & 3.04 & 2.84 & 2.78 & 2.39 & 1.54 & 1.47 & 0.75 & 1.97 & 2.59 & 2.48 & 2.50 & 3.23 & 3.96 & 3.69 & 3.60 & 3.67 \\
\hline SunTrust & 3.23 & 3.26 & 2.53 & 2.82 & 1.68 & 1.56 & 1.75 & 1.99 & 1.08 & 1.77 & 2.24 & 3.33 & 3.79 & 3.75 & 3.78 & 4.27 & 4.26 & 3.94 \\
\hline Fifth Third & 5.42 & - & 5.42 & 4.44 & 4.34 & 2.86 & 3.78 & 2.03 & 0.31 & 2.64 & 3.30 & 5.04 & 5.10 & 4.69 & 4.71 & 5.60 & 4.65 & 4.70 \\
\hline Regions & 2.91 & 2.77 & 2.64 & 3.08 & 2.86 & 2.64 & 2.53 & 1.88 & 1.23 & 2.03 & 1.86 & 2.42 & 4.62 & 5.09 & 5.61 & 5.07 & 5.07 & 4.86 \\
\hline Northern Trust & 2.14 & 2.39 & 3.02 & 2.83 & 2.79 & 1.80 & 1.64 & 1.93 & 1.42 & 3.16 & 3.65 & 2.49 & 3.11 & 3.12 & 2.83 & 2.66 & 3.04 & 2.94 \\
\hline M\&T & 1.41 & 1.54 & 2.23 & 1.51 & 1.41 & 1.49 & 1.79 & 0.95 & 0.55 & 1.09 & 2.16 & 2.34 & 3.17 & 4.37 & 4.10 & 4.65 & 3.90 & 5.00 \\
\hline KeyCorp & 2.12 & 2.33 & 2.73 & 2.94 & 2.35 & 2.68 & 3.01 & 2.58 & 1.95 & 3.56 & 4.19 & 5.88 & 6.02 & 5.70 & 5.80 & 5.93 & 5.27 & 4.84 \\
\hline Comerica & - & 4.81 & 4.85 & 5.29 & 5.43 & 5.20 & 4.65 & 3.99 & 3.23 & 3.99 & 6.53 & 6.28 & 5.76 & 6.06 & 5.85 & 5.69 & 5.88 & 6.35 \\
\hline Huntington & - & 2.12 & 3.62 & 2.80 & 3.18 & 3.19 & 2.87 & 0.81 & -0.20 & 1.74 & 3.42 & 4.20 & 4.69 & 4.77 & 4.13 & 3.78 & 3.00 & 3.30 \\
\hline Zions & 1.34 & 1.98 & 2.06 & 2.53 & 2.80 & 1.37 & 1.98 & 1.70 & 1.85 & 2.12 & 2.99 & 2.77 & 3.09 & 4.02 & 5.48 & 5.63 & 5.49 & 5.57 \\
\hline Average ratio & 2.04 & 1.98 & 2.46 & 2.29 & 2.25 & 1.93 & 2.02 & 1.15 & 0.07 & 1.75 & 2.71 & 3.10 & 3.52 & 3.76 & 3.86 & 4.06 & 3.90 & 3.95 \\
\hline Standard deviation & 1.27 & 1.19 & 1.34 & 1.31 & 1.28 & 1.17 & 1.27 & 1.29 & 1.58 & 1.18 & 1.39 & 1.69 & 1.56 & 1.61 & 1.73 & 1.73 & 1.66 & 1.76 \\
\hline Number of banks with capital sho & 1 & 1 & 0 & 0 & 0 & 0 & 1 & 4 & 9 & 2 & 1 & 1 & 1 & 1 & 1 & 1 & 1 & 1 \\
\hline Number of banks reporting excess capital & 15 & 16 & 17 & 18 & 18 & 18 & 17 & 14 & 9 & 16 & 17 & 17 & 17 & 17 & 17 & 17 & 17 & 17 \\
\hline
\end{tabular}

Note: Negative values denoted by parentheses. Tangible common equity divided by tangible assets. 
Table A6. Market Capitalization to Book Value Ratio.

\begin{tabular}{|c|c|c|c|c|c|c|c|c|c|c|c|c|c|c|c|c|c|c|}
\hline & 2000 & 2001 & 2002 & 2003 & 2004 & 2005 & 2006 & 2007 & 2008 & 2009 & 2010 & 2011 & 2012 & 2013 & 2014 & 2015 & 2016 & 2017Q3 \\
\hline JPMorgan & 2.15 & 1.79 & 1.16 & 1.66 & 1.32 & 1.29 & 1.44 & 1.19 & 0.87 & 1.04 & 0.99 & 0.71 & 0.86 & 1.1 & 1.1 & 1.09 & 1.35 & 1.43 \\
\hline Bank of America & 1.56 & 2.03 & 2.08 & 2.46 & 1.9 & 1.82 & 1.8 & 1.29 & 0.51 & 0.67 & 0.64 & 0.28 & 0.57 & 0.75 & 0.84 & 0.75 & 0.92 & 1.06 \\
\hline Citigroup & 3.98 & 3.26 & 2.12 & 2.58 & 2.31 & 2.17 & 2.3 & 1.3 & 0.52 & 0.62 & 0.84 & 0.43 & 0.64 & 0.8 & 0.82 & 0.75 & 0.8 & 0.92 \\
\hline Wells Fargo & 3.64 & 2.71 & 2.63 & 2.92 & 2.8 & 2.61 & 2.64 & 2.11 & 1.84 & 1.35 & 1.39 & 1.13 & 1.24 & 1.55 & 1.72 & 1.62 & 1.58 & 1.51 \\
\hline U.S. Bancorp & 2.92 & 2.48 & 2.21 & 2.98 & 2.98 & 2.7 & 3.16 & 2.74 & 2.39 & 1.76 & 1.88 & 1.65 & 1.74 & 2.03 & 2.08 & 1.79 & 2.09 & 2.07 \\
\hline BNY Mellon & 6.77 & 4.71 & 2.6 & 3.05 & 2.8 & 2.49 & 2.46 & 1.9 & 1.29 & 1.17 & 1.16 & 0.72 & 0.85 & 1.11 & 1.26 & 1.2 & 1.41 & 1.47 \\
\hline PNC & 3.34 & 2.73 & 1.74 & 2.28 & 2.18 & 2.12 & 2.01 & 1.51 & 1.24 & 1.11 & 1.08 & 0.94 & 0.87 & 1.08 & 1.18 & 1.07 & 1.36 & 1.51 \\
\hline State Street & 6.16 & 4.4 & 2.65 & 3.03 & 2.66 & 2.91 & 3.09 & 2.78 & 1.56 & 1.49 & 1.31 & 1.04 & 1.06 & 1.6 & 1.67 & 1.44 & 1.65 & 1.84 \\
\hline BB\&T & 3.12 & 2.68 & 2.36 & 2.11 & 2.13 & 2.05 & 2.03 & 1.31 & 1.19 & 1.08 & 1.11 & 1.01 & 1.07 & 1.31 & 1.29 & 1.13 & 1.42 & 1.39 \\
\hline SunTrust & 2.27 & 2.16 & 1.83 & 2.07 & 1.67 & 1.56 & 1.73 & 1.24 & 0.61 & 0.58 & 0.81 & 0.48 & 0.75 & 0.95 & 1.01 & 0.88 & 1.2 & 1.26 \\
\hline Fifth Third & 5.69 & 4.68 & 3.97 & 3.93 & 2.96 & 2.22 & 2.27 & 1.46 & 0.61 & 0.78 & 1.12 & 0.91 & 1.01 & 1.33 & 1.17 & 1.04 & 1.36 & 1.32 \\
\hline Regions & 1.74 & 1.71 & 1.77 & 1.85 & 1.54 & 1.47 & 1.32 & 0.83 & 0.41 & 0.44 & 0.66 & 0.41 & 0.67 & 0.89 & 0.89 & 0.74 & 1.11 & 1.14 \\
\hline Northern Trust & 7.74 & 5.03 & 2.69 & 3.33 & 3.23 & 3.14 & 3.37 & 3.75 & 2.38 & 2.01 & 1.97 & 1.34 & 1.59 & 1.86 & 1.95 & 1.99 & 2.2 & 2.17 \\
\hline M\&T & 2.35 & 2.33 & 2.28 & 2.07 & 2.17 & 2.08 & 2.15 & 1.38 & 1.02 & 1.13 & 1.37 & 1.14 & 1.35 & 1.46 & 1.5 & 1.29 & 1.6 & 1.61 \\
\hline KeyCorp & 1.54 & 1.79 & 1.68 & 1.56 & 1.75 & 1.94 & 1.76 & 1.97 & 1.18 & 0.57 & 0.61 & 0.93 & 0.76 & 0.78 & 1.19 & 1.05 & 1.3 & 1.38 \\
\hline Comerica & 2.48 & 2.11 & 1.53 & 1.92 & 2.04 & 1.82 & 1.79 & 1.28 & 0.59 & 0.89 & 1.29 & 0.74 & 0.82 & 1.21 & 1.13 & 0.97 & 1.53 & 1.65 \\
\hline Huntington & 1.72 & 1.79 & 1.89 & 2.26 & 2.26 & 2.08 & 1.86 & 0.91 & 0.52 & 0.72 & 1.28 & 0.94 & 1 & 1.41 & 1.44 & 1.42 & 1.56 & 1.57 \\
\hline Zions & 3.06 & 2.13 & 1.5 & 2.17 & 2.19 & 1.88 & 1.85 & 0.99 & 0.57 & 0.46 & 0.96 & 0.65 & 0.8 & 1.01 & 0.91 & 0.84 & 1.26 & 1.31 \\
\hline Average rat & 3.46 & 2.81 & 2.15 & 2.46 & 2.27 & 2.13 & 2.17 & 1.66 & 1.07 & 0.99 & 1.14 & 0.86 & 0.98 & 1.24 & 1.29 & 1.17 & 1.43 & 1.48 \\
\hline Standard deviation & 1.89 & 1.12 & 0.63 & 0.63 & 0.54 & 0.49 & 0.58 & 0.76 & 0.63 & 0.45 & 0.38 & 0.35 & 0.32 & 0.37 & 0.37 & 0.36 & 0.35 & 0.32 \\
\hline $\begin{array}{l}\text { Number of banks market capital less than } \\
\text { book value }\end{array}$ & 0 & 0 & 0 & 0 & 0 & 0 & 0 & 3 & 9 & 9 & 7 & 12 & 10 & 5 & 4 & 6 & 2 & 1 \\
\hline $\begin{array}{l}\text { Number of banks market capital more than } \\
\text { book value }\end{array}$ & 18 & 18 & 18 & 18 & 18 & 18 & 18 & 15 & 9 & 9 & 11 & 6 & 7 & 13 & 14 & 12 & 16 & 17 \\
\hline
\end{tabular}




\section{References and Notes}

Acharya, Viral, Robert Engle, and Diane Pierret. 2014. Testing Macroprudential Stress Tests: The Risk of Regulatory Risk Weights. Journal of Monetary Economics 65: 36-53. [CrossRef]

Balla, Eliana, Laurel C. Mazur, Edward Simpson Prescott, and John R. Walter, 2017. Comparison of Small Bank Failures and FDIC Losses in the 1986-92 and 2007-13 Banking Crises. Working Paper no. 17-19, Federal Reserve Bank of Cleveland, Cleveland, OH, USA.

Barth, James R., and Stephen Miller. 2018. Benefits and Costs of a Higher Bank "Leverage Ratio". Journal of Financial Stability 38: 37-52. [CrossRef]

Barth, James R., Gerard Caprio Jr., and Ross Levine. 2012. Guardians of Finance: Making Regulators Work for Us. Cambridge: MIT Press.

Basel Committee on Banking Supervision (BCBS). 1988. International Convergence of Capital Measurement and Capital Standards. Basel: Bank for International Settlements, Available online: http:/ /www.bis.org/publ/bcbs04a. htm (accessed on 30 October 2018).

Basel Committee on Banking Supervision (BCBS). 1996. Amendment to the Capital Accord to Incorporate Market Risks. Basel: Bank for International Settlements, Available online: http:/ / www.bis.org/publ/bcbs24.htm (accessed on 30 October 2018).

Basel Committee on Banking Supervision (BCBS). 2004. Amendment to the Capital Accord to Incorporate Market Risks. Basel: Bank for International Settlements, Available online: http:/ /www.bis.org/publ/bcbs107.htm (accessed on 30 October 2018).

Basel Committee on Banking Supervision (BCBS). 2009. Revisions to the Basel II Market Risk Framework-Final Version. Basel: Bank for International Settlements, Available online: http:/ /www.bis.org/publ/bcbs158.htm (accessed on 30 October 2018).

Basel Committee on Banking Supervision (BCBS). 2011. Basel III: A Global Regulatory Framework for More Resilient Banks and Banking Systems_Revised Version June 2011. Basel: Bank for International Settlements, Available online: http:/ / www.bis.org/publ/bcbs189.htm (accessed on 30 October 2018).

Basel Committee on Banking Supervision (BCBS). 2014a. The G-SIB Assessment Methodology—Score Calculation. Basel: Bank for International Settlements, Available online: http://www.bis.org/bcbs/publ/d296.htm (accessed on 30 October 2018).

Basel Committee on Banking Supervision (BCBS). 2014b. Implementation of Basel Standards: A Report to G20 Leaders on Implementation of the Basel III Regulatory Reforms. Basel: Bank for International Settlements, Available online: http:/ / www.bis.org/bcbs/publ/d299.htm (accessed on 30 October 2018).

Basel Committee on Banking Supervision (BCBS). 2017. Basel III: Finalising Post-Crisis Reforms. Basel: Bank for International Settlements, Available online: https:/ / www.bis.org/bcbs/publ/d424.htm (accessed on 30 October 2018).

Begenau, Juliane, and Tim Landvoigt. 2017. Financial Regulation in a Quantitative Model of the Modern Banking System. Available online: http:/ / dx.doi.org/10.2139/ssrn.2748206 (accessed on 30 October 2018).

Board of Governors of the Federal Reserve System. 2012. Comprehensive Capital Analysis and Review 2012: Methodology and Results for Stress Scenario Projections; Washington: Federal Reserve System, p. 5.

Board of Governors of the Federal Reserve System. 2015. Comprehensive Capital Analysis and Review 2015: Assessment Framework and Results; Washington: Federal Reserve System.

Brealey, Richard A. 2006. Basel II: The Route Ahead or Col-de-sac? Journal of Applied Corporate Finance 4: 34-43. [CrossRef]

Chen, Brian, Samuel Hanson, and Jeremy Stein. 2017. "The Decline of Big-Bank Lending to Small Business: Dynamic Impacts on Local Credit and Labor Markets". NBER Working Paper 23843. Available online: http:/ / www.nber.org/papers/w23843 (accessed on 30 October 2018).

Cole, Rebel, and Lawrence J. White. 2017. When Time is Not on Our Side: The Costs of Regulatory Forbearance in the Closure of Insolvent Banks. Journal of Banking and Finance 80: 235-49. [CrossRef]

Demirguc-Kunt, Asli, Enrica Detragiache, and Ouarda Merrouche. 2013. Bank Capital: Lessons from the Financial Crisis. Journal of Money, Credit and Banking 45: 1147-64. [CrossRef]

Egan, Mark, Ali Hortacsu, and Gregor Matvos. 2017. Deposit Competition and Financial Fragility: Evidence from the U.S. Banking Sector. American Economic Review 107: 169-216. [CrossRef]

Elliott, Douglas J. 2010. A Primer on Bank Capital. Washington: Brookings Institution. 
Erel, Isil, Taylor Nadauld, and René M. Stulz. 2014. Why Did Holdings of Highly Rated Securitization Tranches Differ So Much across Banks? Review of Financial Studies 27: 404-53. [CrossRef]

Estrella, Arturo, Sangkyun Park, and Stavros Peristiani. 2000. Capital ratios as predictors of bank failure. Federal Reserve Bank of New York Economic Policy Review 6: 33-52.

Federal Deposit Insurance Corporation. 2014. Regulatory Capital Interim Final Rule; Washington: Federal Deposit Insurance Corporation.

Federal Register. 1989. Capital; Risk-Based Capital Guidelines. January 27, vol. 54, p. 4186, Washington, D.C: Office of the Federal Register.

Federal Register. 1992. Prompt Corrective Action; Rules of Practice for Hearings. September 29, vol. 57, p. 44866, Washington, D.C: Office of the Federal Register.

Federal Register. 1996. Risk-Based Capital Standards: Market Risk. September 6, vol. 61, p. 4186, Washington, D.C: Office of the Federal Register.

Federal Register. 2001. Risk-Based Capital Guidelines; Capital Adequacy Guidelines; Capital Maintenance: Capital Treatment of Recourse, Direct Credit Substitutes and Residual Interests in Asset Securitization. November 29, vol. 66, p. 59614, Washington, D.C: Office of the Federal Register.

Federal Register. 2007. Risk-Based Capital Standards: Advanced Capital Adequacy Framework-Basel II. December 7, vol. 72, p. 69288, Washington, D.C: Office of the Federal Register.

Federal Register. 2012a. Annual Company-Run Stress Test Requirements for Banking Organizations with Total Consolidated Assets Over \$10 Billion Other Than Covered Companies. October 12, vol. 77, p. 62396, Washington, D.C: Office of the Federal Register.

Federal Register. 2012b. Annual Stress Test. October 15, vol. 77, p. 62417, Washington, D.C: Office of the Federal Register.

Federal Register. 2012c. Annual Stress Test. October 9, vol. 77, p. 61238, Washington, D.C: Office of the Federal Register.

Federal Register. 2012d. Risk-Based Capital Guidelines: Market Risk. August 30, vol. 77, p. 53060, Washington, D.C: Office of the Federal Register.

Federal Register. 2012e. Supervisory and Company-Run Stress Test Requirements for Covered Companies. October 12, vol. 77, p. 62378, Washington, D.C: Office of the Federal Register.

Federal Register. 2012f. Supervisory Guidance on Stress Testing for Banking Organizations with More Than \$10 Billion in Total Consolidated Assets. May 17, vol. 77, p. 29458, Washington, D.C: Office of the Federal Register.

Federal Register. 2013. Regulatory Capital Rules: Regulatory Capital Implementation of Basel III, Capital Adequacy, Transition Provisions, Prompt Corrective Action, Standardized Approach for Risk-weighted Assets, Market Discipline and Disclosure Requirements, Advanced Approaches Risk-Based Capital Rule, and Market Risk Capital Rule. October 11, vol. 78, p. 62018, Washington, D.C: Office of the Federal Register.

Federal Register. 2015. Regulatory Capital Rules: Implementation of Risk-Based Capital Surcharges for Global Systemically Important Bank Holding Companies. August 14, vol. 80, p. 49081, Washington, D.C: Office of the Federal Register.

Flannery, Mark. 2014. Maintaining Adequate Bank Capital. Journal of Money Credit and Banking 46: 157-80. [CrossRef]

Haldane, Andrew G. 2011. “Capital Discipline”. BIS Central Bankers' Speeches. Available online: http:/ / www. bis.org/review/r110325a.pdf (accessed on 30 October 2018).

Haldane, Andrew G. 2012. “The Dog and the Frisbee". BIS Central Bankers' Speeches. Available online: https: / / www.bis.org/review / r120905a.pdf (accessed on 30 October 2018).

Herring, Richard. 2016. Less Really Can be More: Why Simplicity \& Comparability Should be Regulatory Objectives. Atlantic Econonomic Journal 4: 33-50.

Herring, Richard. 2018. The Evolving Complexity of Capital Regulation. Journal of Financial Services Research 53: 183-205. [CrossRef]

Hogan, Thomas. 2015. Capital and Risk in Commercial Banking: A Comparison of Capital and Risk-based Capital Ratios. Quarterly Review of Economics and Finance 57: 32-45. [CrossRef]

Hogan, Thomas, and Neil Meredith. 2016. Risk and Risk-based Capital of U.S. Bank Holding Companies. Journal of Regulatory Economics 49: 86-112. [CrossRef] 
International Monetary Fund. 2009. Global Financial Stability Report, Chapter 3. Available online: http:/ / www. imf.org/external/pubs/ft/gfsr/2009/01/pdf/chap3.pdf (accessed on 30 October 2018).

Jones, David. 2000. Emerging Problems with the Basel Capital Accord: Regulatory Capital Arbitrage and Related Issues. Journal of Banking and Finance 24: 35-58. [CrossRef]

Kapstein, Ethan. 1991. Supervising International Banks: Origins and Implications of the Basle Accord. Essays in International Finance, No. 185. Princeton: International Finance Section, Princeton University.

Kapstein, Ethan. 1994. Governing the Global Economy. Cambridge: Harvard University Press.

Karmakar, Sudipto. 2016. Macroprudential Regulation and Macroeconomic Activity. Journal of Financial Stability 25: 166-78. [CrossRef]

Killian, Thomas W. 2016. Total Loss Absorbing Capacity (TLAC). New York: Sandler O'Neill and Partners.

McLaughlin, Patrick A., and Oliver Sherouse. 2018. RegData US 3.1 Annual (dataset). QuantGov. Mercatus Center at George Mason University, Arlington, VA. Available online: https:/ / quantgov.org/regdata/ (accessed on 30 October 2018).

Merton, Robert. 1995. Financial Innovation and the Management and Regulation of Financial Institutions. Journal of Banking and Finance 19: 461-81. [CrossRef]

Miller, Stephen Matteo. 2018. The Recourse Rule, Regulatory Arbitrage and the Crisis. Journal of Regulatory Economics 54: 195-217. [CrossRef]

Mora, Ricardo, and Iliana Reggio. 2017. Alternative diff-in-diffs Estimators with Several Pretreatment Periods. Econometric Reviews. [CrossRef]

Office of the Inspector General. 2015. The Board Identified Areas of Improvement for Its Supervisory Stress Testing Model Validation Activities, and Opportunities Exist for Further Enhancement. Available online: https: / / oig.federalreserve.gov/reports / board-supervisory-stress-testing-model-validation-oct2015.pdf (accessed on 30 October 2018).

White, Eugene. 2013. To Establish a More Effective Supervision of Banking. In The Origins, History, and Future of the Federal Reserve: A Return to Jekyll Island. Edited by Michael D. Bordo and William Roberds. Cambridge: Cambridge University Press, pp. 7-54.

(C) 2018 by the authors. Licensee MDPI, Basel, Switzerland. This article is an open access article distributed under the terms and conditions of the Creative Commons Attribution (CC BY) license (http://creativecommons.org/licenses/by/4.0/). 